Hydrol. Earth Syst. Sci. Discuss., https://doi.org/10.5194/hess-2018-473

Manuscript under review for journal Hydrol. Earth Syst. Sci.

Discussion started: 19 September 2018

(C) Author(s) 2018. CC BY 4.0 License.

\title{
Climate change will increase potential hydropower production in six Arctic Council member countries based on probabilistic hydrological projections
}

\author{
Elena Shevnina ${ }^{1}$, Karoliina Pilli-Sihvola ${ }^{1}$, Riina Haavisto ${ }^{1}$, Timo Vihma ${ }^{1}$, Andrey Silaev ${ }^{2}$
}

$5 \quad{ }^{1}$ Finnish Meteorological Institute, Erik Palménin aukio 1, FI-00560, Helsinki, Finland

${ }^{2}$ National Research University Higher School of Economics, 25/12, Bolshaya Pecherskaya Street, 603155, Nizhny Novgorod, Russia

Correspondence to: Elena Shevnina (elena.shevnina@fmi.fi)

Abstract. Potential hydropower production for 2020-2050 is calculated for 173 catchments located over the territories of

10 Finland, Sweden, Norway, the Russian Federation, Canada and the United States. The results are based on hydrological river runoff projections assessed together with their exceedance probabilities. The annual runoff rate of particular exceedance probability was modelled with the Pearson type 3 distribution from three parameters (mean values, coefficient of variation and coefficient of skewness) simulated by the probabilistic hydrological MARcov Chain System (MARCS) model. The probabilistic projections of annual runoff were simulated from outputs of four global climate models under three

15 Representative Concentration Pathways (RCP2.6, RCP4.5 and RCP8.5). The future potential hydropower production was evaluated based on annual runoff of low and high exceedance probabilities, and then aggregated at a country level. Under forcing from climate models that project a large increase in precipitation (CaEMS2 and MPI-EMS-LM), the expected potential hydropower production in the six countries increased by 14.0 to $18.0 \%$ according to the projected values of annual runoff rate on exceedance probabilities of 10 and $90 \%$. This increase in water resources allows for 10-15\% more hydropower energy generation by rivers located in Russia, Finland, Norway, and Sweden. For the USA and Canada, the potential hydropower production is projected to increases by 4.0-9.0\%. Under forcing from climate models that project a smaller increase in precipitation (HadGEM2-ES and INMCM4), the increase of potential hydropower production by 2050 was predicted to be $2.1-8.4 \%$ over the six countries considered.

\section{Introduction}

Water has always been a key natural resource in energy production. Nowadays, hydropower plant operators use deterministic

25 and probabilistic hydrological forecasts on stream flow water runoff (Schwanenberg et al., 2014; Xu et al., 2014; Domínguez and Rivera, 2010; Shevnina, 2001) to optimize rules of surface runoff regulation and energy production in hydropower plants (Tucci et al., 2008), and to prevent losses due to extreme runoff events. Engineering hydrology introduces the extreme runoff events in terms of exceedance probability as multi-year stream flow runoff values of low or high occurrences (van Gelder et al., 2006; Wilson, 1990; Rozhdestvenskiy and Chebotarev, 1984). In hydropower industry, the extreme runoff events result to 
Hydrol. Earth Syst. Sci. Discuss., https://doi.org/10.5194/hess-2018-473

Manuscript under review for journal Hydrol. Earth Syst. Sci.

Discussion started: 19 September 2018

losses caused by water spills due to flooding, or lead to interruptions in operation of hydropower plants due to water shortages. On the long-term, the hydropower industry is sensitive to changes in water resources available for energy production, and changing patterns in the extreme runoff events (Döll and Schmied, 2012; Madsen et al., 2013; Milly at al., 2008).

Long-term hydrological predictions have become important for hydropower producers due to observed trends in the surface river runoff, which are related to climatological changes in air temperature and precipitation. According to the Intergovernmental Panel on Climate Change (IPCC) Fifth Assessment Report (AR5; IPCC, 2013), the anomaly in annual precipitation rate (mm year-1) over the Arctic has about 30-60\%, and precipitation generally tends to increase during the past decades as shown in Fig. 2.28 of the IPCC report (IPCC, 2013). Trends in annual mean precipitation in the Arctic and northern mid-latitudes show a large spatial variation, and are sensitive to the time period addressed. Further, inaccuracies in snow fall observations (Alexandrov et al., 2005) contribute to the inaccuracy of precipitation trends. Observations suggest a general increase in annual precipitation in circumpolar high-latitude regions over recent decades (Vihma et al., 2016; Roshydromet, 2014; Hartmann et al., 2013;). Increases have been reported, among others, for northern Canada and a large part of Russia. In the mid-latitude regions of the United States, the long-lasting drought generated by the decrease in annual precipitation during last decade (Barnstone and Lyon, 2016). Winter and summer precipitation have decreased in the headwater parts of the Mackenzie River basin

45 (Yip et al., 2012), and summer and autumn precipitation have decreased in central Eurasia (Bogdanova et al., 2010). The general increase in precipitation is due to the global warming trend (Hartmann et al., 2013).

In Northern Hemisphere land areas, the annual mean precipitation typically increases towards south, as the water-holding capacity of air depends on a temperature. Coastal regions, in particularly east of oceans, represent the largest deviations from this northsouth trend. Precipitation amounts are anomalously large in the west coast of Canada, south-west coast of Alaska, north-west coast

50 of the USA, and along the Norwegian coast (Vihma et al., 2016). Lowest precipitation amounts are observed in northern Siberia and Canadian Arctic archipelago.

Rosmann et al. (2016) revise the observed global river runoff time-series, and find that the highest number of statistically significant trends are detected in the multi-year time series of an annual stream flow runoff. The trends in observed surface river runoff motivate hydrologists to revise the basic assumption behind the long-term water resources and extreme runoff predictions, because historical observations do not provide information on future risks connected to water resources and stream flow runoff extremes (Tananaev et al., 2016; Madsen et al., 2013; Milly at al., 2008). The annual stream flow runoff serves water resource for the hydropower industry, which is an important element on an energy production in the Arctic Council member countries especially on the Nordic countries (FI, NO, SE) (Norden, 2018). This study focused on the annual surface river runoff, which was considered as a random variable analysed on the basis of multi-year time series of observed annual river discharges s or stream flow rates.

To express a general relationship between water use and water resources available, numerous use-to-resource ratios are suggested (Brauman et al. 2016; Tidwell et al., 2012). Examples include the Water Stress Index, defined as the ratio of available river runoff to population in a basin (Falkenmark et al., 1989) and the water supply stress index, which considers 
Hydrol. Earth Syst. Sci. Discuss., https://doi.org/10.5194/hess-2018-473

Manuscript under review for journal Hydrol. Earth Syst. Sci.

Discussion started: 19 September 2018

(c) Author(s) 2018. CC BY 4.0 License.

regional trends in both water supply and demand (e.g., Averyt et al., 2013). Roy et al (2005) take a similar approach except that their metric is constructed as the ratio of water withdrawal to effective precipitation. Other metrics are based on multiple criteria that are aggregated and related to some threshold of water availability/sustainable development (Xu and Wu, 2017). For hydropower, a potential hydropower production (PHP) is a traditional indicator, usually evaluated from the mean values of the annual river discharges (Parkinson and Djilali, 2015; Hamidudu and Killingtveit, 2012). However, focusing solely on the mean value is not sufficient, as future risks on water resources are posed by changes in the temporal dynamics of river

70 discharge (Döll and Schmied, 2012) and, on hydropower production, particularly by changes in the runoff extremes (Blackshear et al., 2011). Water engineering defines the stream flow runoff extremes as values of low/high exceedance probabilities, which are estimated from tails of exceedance probability curves (EPCs) of river runoff. The exceedance probability indicates a likelihood that a particular runoff value will be exceeded. The probabilistic hydrological projection gives an opportunity to increase our understanding of future risks on hydropower generation through evaluation of the potential energy production expressed in terms of probability.

While many studies are directed to the evaluation of PHP, they are only based on estimates of the future mean value for the annual stream flow runoff. For example, Madany and Lund (2010) assess the projected mean values for annual river runoff from a proportion to historical mean values for California, and use these as inputs in an optimization model to define optimal regimes of future hydropower generation (Madany and Lund, 2009). Lehner et al. (2005) use the global-scale WaterGAP

80 model (Alcamo et al., 2003), taking into account both climate and socio-economic changes, to evaluate PHP for Europe. A hydrological rainfall-runoff model (Döll et al., 2003) is used to simulate the mean values of annual river runoff based on future precipitation and air temperature available as climate model outputs. Hamududu and Killingtveit (2012) provide a state-of-the-art assessment for global installed hydropower capacity, and focus on the future changes in PHP based on projections from 12 global climate models (Milly et al., 2005). However, the results of these and many other studies do not

85 provide estimates on how the future extreme variability of water resources may affect potential hydropower production. In this study, the potential hydropower production for the river runoff values of low/high exceedance probabilities are evaluated over 173 catchments located in six out of the eight member countries of the Arctic Council for 2020-2050: Finland (FI), Sweden (SE), Norway (NO), Russian Federation (RF), Canada (CA) and the United States (US). The share of hydropower production out of the total electricity generation in each country, except for the US and RF, is $20 \%$ or over (World Development Indicators on

90 http://wdi.worldbank.org/table/3.7). In Norway, it is over 95\%, in Canada almost 60\%, in Sweden 40\% and in Finland 20\%. The two other Arctic Council member countries, Iceland and the Kingdom of Denmark also have major freshwater resources and hydropower generation. However, they were excluded from the analysis as no data for large (1,000-50,000 $\left.\mathrm{km}^{2}\right)$ watersheds located in Iceland and Greenland were found. The data and methodological details are described in Section 2. The results are shown in Section 3, and Section 4 discusses the limitations of our study and future research needs. Among the countries considered, the three

95 Nordic countries (FI, NO, SE) do not have plans to build new hydropower capacity in the near future. The Russian Federation has some facilities planned, and the USA and Canada are currently planning and building major hydropower facilities 
Hydrol. Earth Syst. Sci. Discuss., https://doi.org/10.5194/hess-2018-473

Manuscript under review for journal Hydrol. Earth Syst. Sci.

Discussion started: 19 September 2018

(c) Author(s) 2018. CC BY 4.0 License.

(http://atlas.freshwaterbiodiversity.eu/atlasApp/full/index.html?map=3.4.3-global-hydropower-dams) based on Zarfl et al., (2015). This also affects how the information of future climate change can be incorporated in decision making in the different phases of hydropower plant management, including planning, upgrading and operation of the plants. This is briefly discussed in Section 5, which concludes the paper.

\section{Method and Data}

\subsection{Method}

The modeling approach used in this study consists of three components: an input (model forcing), the model (a conceptual abstraction or mathematic equation) and an output (simulation results). Figure 1 shows a schematic representation of the flow of the models and their outputs as well as the forcing data used with the framework of this study. The study method includes climatological, hydrological and economical models, which form the chain from climate projections via water resource projections to economic indicators and indexes. The historical yearly time series of the annual river discharges serve as the input to estimate the mean, coefficient of variation (CV) and coefficient of skewness (CS) of annual runoff. These time series were observed on 326 sites of the national hydrological networks of the six Arctic Council member countries. The yearly time series of annual precipitation amount were extracted from open sources and used to estimate historical and protected mean values to set-up and force the probabilistic hydrological MARkov Chain System model MARCS (the middle block on Hydrology column in Figure 1).

The output of the MARCS model is the exceedance probability curve of annual river runoff (expressed in units of stream flow rate or of water discharge). In this study, the values of runoff of low and high exceedance probabilities were used to calculate the 115 potential hydropower production for the projected period (the upper block of the Hydropower column on Figure 1). The simple relationship between energy production and water discharge on any site was used as the economic model (see details further).

\subsubsection{Climatology}

In this study, the historical observations on annual precipitation amount and river water discharge were used in estimations of the non-central moments, the first (mean value), second and third moments. The estimates of all three non-central moments were used to estimate mean values, coefficient of variation and coefficient of skewness of the river water discharges at gauging sites to set-up the hydrological MARCS model. The mean values were only estimated from the time series of annual precipitation amount for the historical period as well as for the projected period (2020-2050). The outputs from four global climate models under three climate change scenarios were used in this study (see further details in Section 2.2). 
Hydrol. Earth Syst. Sci. Discuss., https://doi.org/10.5194/hess-2018-473

Manuscript under review for journal Hydrol. Earth Syst. Sci.

Discussion started: 19 September 2018

(c) Author(s) 2018. CC BY 4.0 License.

\section{$125 \quad 2.1 .2$ Hydrological model}

An Advanced Frequency Analysis (AFA) suggested by Kovalenko (1993) was applied to evaluate the probabilistic projections of annual river runoff. The AFA method combines traditional modeling methods (Alcamo et al., 2003) with frequency analysis methods (van Gelder et al., 2006), and it is a part of the Fokker-Plank-Kolmogorov equation approach (Rosmann and Domínguez, 2017; Domínguez and Rivera, 2010; Kovalenko, 1993). The main idea of the AFA method is to simulate statistical estimators of

130 annual river runoff (mean, variation and skewness) from the mean annual precipitation (Shevnina et al., 2017; Kovalenko et al., 2010; Kovalenko, 1993; Pugachev et al., 1974). In this study, the MARCS model (Shevnina and Krasikov, 2018; Shevnina and Gaidukova, 2017; Shevnina, 2015) was used to simulate the mean, CV and CS of annual runoff rate (ARR) for the selected gauging sites (see black dots on Figure 2).

To set up the MARCS model, the historical ARR time series (Table 1) were analysed for trends, stability of variance and

135 mean by applying the Spearman's Rank-Correlation Test (SRC), the Fisher's F-test (FR) and Student's t-test (ST), as suggested in Dahmen and Hall (1990). The FR and ST values were evaluated using sub-series divided at a fixed year (1975), and the values of SRC were evaluated by a "floating point” technique (Shevnina et al., 2017). The same technique was applied to define the reference period, and its length varied for the selected gauging sites. The reference period covers a period in the past without statistically significant trends in the observed time series of annual runoff. In our study, the reference period was specific for each catchment. For the reference period, the estimates of the three first non-central statistical moments were evaluated from the historical time series of ARR with the method of moments (Rozhdestvenskiy and Chebotarev, 1984). The projected period chosen is 2020-2050 for all gauging sites.

To parametrize and force the MARCS model, the mean values of annual precipitation were evaluated for both the reference and projected period with gridded climatological datasets. Thus, the means of annual precipitation were calculated at a grid node nearest to a centroid of a catchment outlining a gauging site. The projected mean values of annual precipitation were evaluated from outputs of four global climate models and corrected with the delta method (Fowler et al., 2007).

The MARCS model simulates three non-central moments of ARR by allowing the calculation of the Pearson type 3 (Pt3) probability distribution parameters used in water engineering (Koutrouvelis and Canavos, 1999; Rozhdestvenskiy and Chebotarev, 1974; Matalas and Wallis, 1973). In this study, only two non-central moments of ARR were simulated for each 150 projection of the future climate, which were then used to calculate CV. The projected CS was evaluated with a CS/CV ratio considered to be constant for the reference and projected periods (Shevnina et al., 2017; Kovalenko et al., 2010).

To evaluate the projected annual runoff rate of a low/high exceedance probability, a look-up table (Salvosa, 1930) was used. First, the ordinates of the Pearson type 3 (Pt3) distribution were estimated for each river basin, and then further applied in calculation of the annual runoff rate of high/low exceedance probability. The results were aggregated at a country level to 155 estimate the changes on the PHP. 
Hydrol. Earth Syst. Sci. Discuss., https://doi.org/10.5194/hess-2018-473

Manuscript under review for journal Hydrol. Earth Syst. Sci.

Discussion started: 19 September 2018

(c) Author(s) 2018. CC BY 4.0 License.

\subsubsection{Potential hydropower production}

Energy generation is among the most important indicators of a hydropower plant efficiency. The PHP (in Watts) provides an estimate of the energy production. Hydropower engineering handbooks (e.g., Obrezkov, 1988) provide a simple relationship between PHP and water resources, formulated as follows:

$$
P H P=\rho \zeta H Q
$$

where $Q$ is the mean annual water discharge $\left(\mathrm{m}^{3} \mathrm{~s}^{-1}\right)$ at a plant site, $H$ is a plant-specific hydraulic head (m), and $\rho \quad$ and $\zeta$ are water density $\left(\mathrm{kg} \mathrm{m}^{-3}\right)$ and gravity acceleration $\left(\mathrm{m} \mathrm{s}^{-2}\right)$, respectively.

Eq. 1 presents a general relation between energy production and water resource (annual runoff) in production facilities. The PHP depends on the available annual river runoff (a resource) and site-specific hydropower plant equipment (a technology), and

165 allows estimation of an average hydropower production in global and regional scales for the near future (Parkinson and Djilali, 2015; Hamududu and Killingtveit, 2012) in assumption that the technology will not change. In our study, PHP was considered a random variable linearly related to the annual runoff, which is also defined as a random variable ( $\left.P H P_{p}=\rho \xi H Q_{p}\right)$. The future relative change in PHP (dPHP) was evaluated on the basis of the mean annual runoff and the upper ( $\mathrm{p}=10 \%$, high flow) and lower ( $\mathrm{p}=90 \%$, low flow) tails of ARR with an assumption that the technology in hydropower production remains same during the 170 next 30 year. Thus, dPHP is only proportional to changes in the mean ARR as well as ARR of low and high probability of exceedance. The MARCS model outputs were used to evaluate the changes of PHP for the 173 catchments located over the six Arctic Council member countries for the period of 2020-2050.

\subsection{Data}

To set-up, parametrize and force the MARCS model for the selected catchments, the observed yearly time series of water discharge

175 and precipitation as well as of the precipitation for the projected period were collected from open-source datasets. The historical time series of water discharge were extracted from the Global Runoff Data Center (GRDC), as monthly series for 326 gauging sites. The sites are located in the territories of Finland, Sweden, Norway, Russia, Canada and United States (Table 1). The observations cover a period of 1863-2015.

The average catchment area of the selected sites is $12,000 \mathrm{~km}^{2}$. The length of the time series varies from 30 to 151 years, and 180 exceeds 80 years on average. The Eurasian part of the Arctic is presented by 147 gauges, and 179 gauges are distributed over North America. The annual discharges were calculated from monthly discharges, and then expressed as ARR (stream flow per unit basin area, $\mathrm{mm} \mathrm{yr}^{-1}$ ). If the ARR time series was shorter than 35 years or included gaps of more than 10 years, the time series was excluded from further study. A total of 219 gauging sites fulfilled the required criteria on time series length and gaps. The inhomogeneity in the observed time series of ARR was detected by the Student t-test (ST), the Fisher's F-test 185 (FR), and the Spearman Rank-Correlation Test (SRC). 
Hydrol. Earth Syst. Sci. Discuss., https://doi.org/10.5194/hess-2018-473

Manuscript under review for journal Hydrol. Earth Syst. Sci.

Discussion started: 19 September 2018

The time series of annual precipitation rate $\left(\mathrm{mm} \mathrm{yr}^{-1}\right)$ for 1900 to 2010 were extracted from the UDel_AirT_Precip dataset provided by NOAA/OAR/ESRL PSD, Boulder, Colorado, USA, via their web site at http://www.esrl.noaa.gov/psd/. The dataset of the Coupled Model Inter-comparison Project 5, CMIP5 (Taylor et al., 2012) was used to force the MARCS model. The model forcing was evaluated for 2020-2050 from the outputs of the four climate models HadGEM2-ES (Collins et al., 2011), INMCM4 (Volodin et al., 2010), CaEMS2 (Chylek et al., 2011) and MPI-ES-LR (Giorgetta et al., 2013) under three Representative Concentration Pathways (RCP2.6, RCP4.5 and RCP8.5).

\section{Results}

\subsection{The model set-up: reference period}

Figure 2 shows the gauges with the observed time series of river water discharge. The ARR time series were analysed for

195 trends and the stability of mean and variance. Statistically significant trends were detected in $25 \%$ of the ARR time series, observed mostly south of the Arctic Circle. These trends may be related to artificial water regulations or natural factors, i.e. climate change. We do not explore the reasons for the trends here, and simply exclude the non-homogeneous ARR time series from the analysis.

For the remaining 208 catchments, the inverse of runoff coefficient (IRC) was calculated by dividing the mean annual 200 precipitation rate by the mean annual runoff rate. The IRC generally reflects watersheds' physiography, and gives estimates on portions of evaporation and surface water runoff in total precipitation (Kovalenko, 2011; Sokolovskiy, 1968). The closer the IRC value is to 1.0, the larger is the portion of surface runoff in precipitation. Outliers, i.e., the catchments with the IRC values less than 1.0 or more than 7.0 (the red dots in Figure 3a) were also excluded from the further study, since such values must be caused by some specific factors. For instance, if IRC $<1.0$ it generally means that the surface runoff exceeds incoming precipitation. This case may occur in a river basins with multi-year artificial regulation. When IRC $>7.0$ the portion of surface runoff in precipitation is very small, and almost all water is evaporated (Kovalenko, 2011).

To set-up the MARCS model, the mean values of annual precipitation rate (PRE, Figure 3b), first and second non-central moments (M1 and M2, Figure $3 \mathrm{c}$ and d) as well as the third non-central moment (not shown) were estimated for the reference period. Then the estimates of the three moments of ARR were used to calculate the CS/CV ratio (not shown) applying the basic parameterization scheme (Shevnina, 2015; Kovalenko, 1993). This parameterization provides over $80 \%$ of successful hindcasts made on historical data (Shevnina et al., 2017; Kovalenko, 1993).

Most surface water resources available for hydropower generation in the case study area are located over the North American coast, in Fennoscandia and western part of the Russian Federation. In the coastal areas, surface water resources mostly depend on precipitation; the role of evaporation is smaller because runoff is enhanced by orography and, in summer (when 215 precipitation amounts are generally largest), surface temperatures are usually relatively low compared with inland regions (Jin, 2004). Figure 2d shows that the highest mean values of ARR are obtained on coastal areas with maritime climate, where the mean values of annual precipitation rate are also high (Figure 2b). 
Hydrol. Earth Syst. Sci. Discuss., https://doi.org/10.5194/hess-2018-473

Manuscript under review for journal Hydrol. Earth Syst. Sci.

Discussion started: 19 September 2018

The estimate for the second non-central moment (Figure 2c) also shows the maximum values in these regions, where the range of the inter-annual variability of water resources is higher than for the inland areas. This is probably related to largescale atmospheric circulation. The coastal zones of North America and Norway are the regions where the annual mean precipitation reaches its maxima. Much of the precipitation is related to advection of moist marine air masses, carried by transient cyclones, to the coastal zone where orographic lifting results in precipitation (e.g., Jakobson and Vihma, 2010). Hence, inter-annual variations in the cyclone activity and tracks result in large variations in precipitation and further in water resources. Inter-annual variations in the cyclone activity and tracks are large also in inland areas but, as the magnitude of precipitation is smaller, their effect on the second non-central moment remains smaller.

Table 2 provides a summary of the MARCS model setup over the 173 watersheds studied. The results are grouped by country to show the basic statistics for IRC, M1, PRE, CV and CS/CV of ARR evaluated from the historical time series. For the catchments located on Norway, the IRC values are about 1.0. This generally means that annual precipitation mostly feeds surface runoff on rivers regulated by numerous hydropower plants located over the catchments. The losses from evaporation

230 are minor. The IRC maxima were obtained for the rivers located in the United States, where the role of evaporation is high, especially for inland catchments. The IRC values are approximately similar for the watersheds located in Finland, Sweden, Russia and Canada.

\subsection{The model forcing: projected period 2020-2050}

The mean values of annual precipitation rate over the period 2020-2050 ( $\mathrm{PRE}_{2050}, \mathrm{~mm} \mathrm{yr}^{-1}$ ) were obtained from the outputs of 235 HadGEM2-ES, CaEMS2, INMCM4 and MPI-ES-LR climate models under the RCP2.6, RCP4.5 and RCP8.5 scenarios. Table 2 shows the summary for the expected changes in $\mathrm{PRE}_{2050}$ averaged over the catchments considered. The values of $\mathrm{PRE}_{2050}$ slightly vary over the RCP scenarios, and different climate models suggest different ranges for the future PRE 2050 : the HadGEM2-ES and INMCM4 predict a small decrease on annual precipitation rate up to 5.2\% (Table 3, HAD-26), whereas the CaEMS2 and MPI-ES-LR models propose an increase of the PRE 2050 up to $4.8 \%$ (Table 3, CAD-26). Figure 4 shows the 240 relative changes in the mean annual precipitation rate ( $\mathrm{dPRE}_{2050}$, \%) calculated by dividing the difference between projected $\left(P R E_{2050}\right)$ and reference (PRE) values by the reference (PRE) value. As the INMCM4 model gives results very similar to those from the HadGEM2-ES, we do not present them in Figure 3 and further figures but only in the tables.

Based on the range of the predicted $\mathrm{dPRE}_{2050}$, the climate models used can be divided in two types. The CaEMS2 and MPIES-LR models suggest twice stronger increase of annual precipitation rate than the HadGEM2-ES and INMCM4 models 245 (Table 3, Figure 4). The dPRE 2050 values for more than $10 \%$ were predicted for a number of catchments (dots with yellow to red colors in Fig. 4) with the highest changes up to 60 \% in Eastern Siberia. In contrast, the HadGEM2-ES and INMCM4 models produced no changes or a slight decrease of annual precipitation rate for most of the catchments. In this case, the $\mathrm{dPRE}_{2050}$ values varied within 10 \%, (blue and green dots in Figure 4). 
Hydrol. Earth Syst. Sci. Discuss., https://doi.org/10.5194/hess-2018-473

Hydrology and

Manuscript under review for journal Hydrol. Earth Syst. Sci.

Discussion started: 19 September 2018

Earth System

(C) Author(s) 2018. CC BY 4.0 License.

Sciences

Discussions

(c) (i)

\subsection{The model output: annual runoff}

250 The projected values for two non-central moments of ARR were simulated for each climate model and RCP scenario combination, and two parameters of the Pt3 distribution, denoted as $\mathrm{M}_{2050}$ and $\mathrm{CV}_{2050}$, were calculated following Rozhdestvenskiy and Chebotarev (1974) and Elderton and Johnson (1969). Then, the relative changes $\mathrm{dM} 1_{2050}\left(\mathrm{dM} 1_{2050}=\right.$ $\left.\left(\mathrm{M}_{2050}-\mathrm{M} 1\right) / \mathrm{M} 1, \%\right)$ and $\mathrm{dCV}_{2050}\left(\left(\mathrm{CV}_{2050}-\mathrm{CV}\right) / \mathrm{CV}\right.$, \%) were used to classify the catchments into six classes based on thresholds. Kovalenko (1993) suggested a classification based on modelling errors inherent to simulated parameters of Pt3

255 distribution, and defined the thresholds to be considered significant for the mean value and CV of ARR. In our study, the thresholds of $-10 \%<\mathrm{dM} 1_{2050}<10 \%$ and $-20 \%<\mathrm{dCV}_{2050}<20 \%$ were considered significant according to Kovalenko (1993). The projected $\mathrm{CV}_{2050}$ vary a little compared to the $\mathrm{CV}$ reference values under all climate model and RCP scenario combinations considered. The relative changes $\mathrm{dCV}_{2050}$ were within the thresholds $-20 \%<\mathrm{dCV}_{2050}<20 \%$, thus they were neglected during watersheds selection.

260 Based on the outputs of HadGEM2-ES and INMCM4 models, the MARCS model predicted lowest $\mathrm{dM} 1_{2050}$ values in a majority of the catchments. However, $\mathrm{dM}_{2050}$ exceeding $10 \%$ was projected only for a fP26 (Figure 5, b). The changes in the projected mean values of ARR were estimated to be in a similar range under the CaEMS2 and MPI-ESM-LM models. This range is about twice more than for the $\mathrm{dM} 1_{2050}$ values calculated from the forcing by the HadGEM2-ES and INMCM4 models (Figure 5 a,c,d,f). The forcing by the MPI-EMS-LM under the RCP85 results on a highest increase of mean values of

265 ARR; more than 30-40\% increase in catchments located in the Siberian territories of Russia as well as the Yukon territory of Canada. In the Nordic countries, the increase of the mean values of ARR was projected to be up to 15-20\% in most of the catchments with the MPI-EMS-LM and CaEMS2 climate models (Figure 5 a,c,d,f; Table 4).

The values of $\mathrm{M}_{2050}$ and $\mathrm{CV}_{2050}$ were evaluated on average over all catchments located in a particular country to provide a "country level” analysis based on the probabilistic projections of ARR. The values of $\mathrm{M}_{2050}$ and $\mathrm{dCV} \mathrm{V}_{2050}$ were averaged over

270 the catchments selected, and then classified into two cases: "wet” forcing and "dry” forcing. The wet forcing summarized the results under the CaEMS2 and MPI-EMS-LM models whereas the dry forcing provided the estimates under the HadGEM2ES and INMCM4 models (Table 4).

Comparing the reference values of ARR reveals that the projected values of $M 1_{2050}$ increase by $5.0-15.0 \%$ under the wet forcing and there is a significant increase in water resources in the six Arctic Council member countries. Under the "dry"

275 climate forcing, the increase varied between 1.5 and $7.0 \%$, and thus is considered to be insignificant. Also the dCV 2050 under both wet and dry forcing is found to be insignificant (Table 5).

To evaluate the projected annual runoff rate $\left(\mathrm{ARR}_{2050}\right)$ of low and high exceedance probability, the Pearson type 3 (Pt3) distribution was applied (Koutrouvelis and Canavos, 1999; Rozhdestvenskiy and Chebotarev, 1974; Matalas and Wallis, 1974). Following the look-up table applied in the engineering hydrology (Salvosa, 1930), the ordinates of Pt3 distribution

280 were evaluated for two exceedance probabilities (k10 and k90 in Table 6) based on the projected $\mathrm{CV}_{2050}$ and CS/CV ratio averaged on a country level (Table 5). These ordinates were further used in calculation of the annual runoff rate of high 
Hydrol. Earth Syst. Sci. Discuss., https://doi.org/10.5194/hess-2018-473

Hydrology and

Manuscript under review for journal Hydrol. Earth Syst. Sci.

Discussion started: 19 September 2018

Earth System

(C) Author(s) 2018. CC BY 4.0 License.

Sciences

Discussions

(c) (i)

(ARR10 2050 ) and low (ARR90 2050 ) exceedance probability. ew watersheds located in the west coast of Canada, the east coast of the United States and eastern parts of European Russia. Among the RCP scenarios, the highest values of $\mathrm{dM}_{2050} \mathrm{were}$ predicted under RCP26 (Figure 5, b). The changes in the projected mean values of ARR were estimated to be in a similar range under the CaEMS2 and MPI-ESM-LM models. This range is about twice more than for the $\mathrm{dM} 1_{2050}$ values calculated from the forcing by the HadGEM2-ES and INMCM4 models (Figure 5 a,c,d,f). The forcing by the MPI-EMS-LM under the RCP85 results on a highest increase of mean values of ARR; more than $30-40 \%$ increase in catchments located in the Siberian territories of Russia as well as the Yukon territory of Canada. In the Nordic countries, the increase of the mean values of ARR was projected to be up to $15-20 \%$ in most of the catchments with the MPI-EMS-LM and CaEMS2 climate models (Figure 5 a,c,d,f; Table 4).

The values of $\mathrm{M1}_{2050}$ and $\mathrm{CV}_{2050}$ were evaluated on average over all catchments located in a particular country to provide a "country level” analysis based on the probabilistic projections of ARR. The values of $\mathrm{M}_{2050}$ and $\mathrm{dCV} \mathrm{V}_{2050}$ were averaged over the catchments selected, and then classified into two cases: "wet” forcing and "dry" forcing. The wet forcing summarized the results under the CaEMS2 and MPI-EMS-LM models whereas the dry forcing provided the estimates under the HadGEM2-

295 ES and INMCM4 models (Table 4).

Comparing the reference values of ARR reveals that the projected values of $\mathrm{M} 1_{2050}$ increase by $5.0-15.0 \%$ under the wet forcing and there is a significant increase in water resources in the six Arctic Council member countries. Under the "dry" climate forcing, the increase varied between 1.5 and $7.0 \%$, and thus is considered to be insignificant. Also the $\mathrm{dCV}_{2050}$ under both wet and dry forcing is found to be insignificant (Table 5).

300 To evaluate the projected annual runoff rate $\left(\mathrm{ARR}_{2050}\right)$ of low and high exceedance probability, the Pearson type 3 (Pt3) distribution was applied (Koutrouvelis and Canavos, 1999; Rozhdestvenskiy and Chebotarev, 1974; Matalas and Wallis, 1974). Following the look-up table applied in the engineering hydrology (Salvosa, 1930), the ordinates of Pt3 distribution were evaluated for two exceedance probabilities (k10 and k90 in Table 6) based on the projected $\mathrm{CV}_{2050}$ and CS/CV ratio averaged on a country level (Table 5). These ordinates were further used in calculation of the annual runoff rate of high $305($ ARR10 2050$)$ and low (ARR90 2050 ) exceedance probability.

\subsection{Potential hydropower production}

The changes in the potential hydropower production (dPHP) were estimated to be simply proportional to the changes of ARR $\left(d A R R_{2050}\right)$. The $\mathrm{dARR}_{2050}$ was evaluated on the basis of the mean values of ARR and the values of low and high exceedance probabilities (dARR10 2050 and dARR90 2050 ) under the wet and dry climate forcing. It was assumed that the technology in 310 hydropower production (such as hydraulic heads and efficiency of water turbines) remains same during the next 30 year. Thus, it was assumed that dPHP only depended on dARR, dARR10 ${ }_{2050}$ and dARR90 2050 (Figure 6).

Over the six Arctic Council member countries, the expected potential hydropower production ( $\mathrm{PHP}_{2050}$ ) increased by 14-18 \% according to the projected values of ARR10 $2050 / A R R 90_{2050}$ under the wet climate forcing. This increase in water resources allows for 10-15 \% increase in hydropower generation in Russia and Fennoscandia (FI, NO, SE) according to the forcing by the CaEMS2 
Hydrol. Earth Syst. Sci. Discuss., https://doi.org/10.5194/hess-2018-473

Manuscript under review for journal Hydrol. Earth Syst. Sci.

Discussion started: 19 September 2018

(C) Author(s) 2018. CC BY 4.0 License.

and MPI-EMS-LM climate models. For the United States and Canada, the expected potential hydropower production increased by 4.0-9.0 \%. Under the forcing by the HadGEM2-ES and INMCM4 climate models (dry forcing), the $\mathrm{dPHP}_{2050}$ was predicted to be 2.1-8.4\% over the six countries considered.

\section{Discussion}

Several features of the current version of the MARCS model should be analyzed more carefully to understand its capacity to provide reliable projections of future runoff and potential hydropower production. Climate models simulate meteorological variables in a grid, and the values are assumed to be representative of each grid box. As the global climate models have a coarse spatial resolution, this assumption becomes critical for physically based and spatially distributed hydrological models (Hostetler, 1994). In this case, regional-scale climatology usually serves as the meteorological forcing for the physically based basin-scale hydrological models (Xu, 1999). The sensitivity of the MARCS model to spatial resolution of forcing by global and regional

325 climate models is a topic for a further study.

One major benefit of using the MARCS model is that it simulates the mean, CV and CS of annual runoff, allowing the calculation of the parameters of exceedance probability curves (i.e. Pt3) with little computational burden compared to physically based hydrological models. The MARCS model produces the probability distribution of runoff from statistics of meteorological variables, and it requires less resources. Thus, the exceedance probability curves of AAR for a number of catchments are simulated from the 330 output of a single climate model without special requirements to computational facilities. It makes the MARCS model useful in regional-scale estimations on extreme floods, droughts and the risks related to their occurrence (Shevnina et al., 2017; Shevnina, 2015; Shevnina, 2014). In our study, the MARCS model was forced by a mean annual precipitation rate of a single climate projection; however, it can be also applied on ensemble of climate projections (Tebaldi and Knutti, 2007). Then, the probabilistic projection of annual runoff allows producing "two-dimensional” version of a probabilistic hydrological projection. In this case, the

335 first dimension indicates an ensemble statistics of annual runoff rate of a particular exceedance probability (to be presented by the second dimension). Ensemble modeling is a topic for a continuation study.

In our data on ARR time series, a trend and non-homogeneity were detected in about $25 \%$ of the time series observed on the watersheds located mostly south of $60^{\circ} \mathrm{N}$. This is in line with the results in Rosmann et al. (2016), who detected trends in observed time series of daily, monthly and annual precipitation, air temperature and river discharge; the highest number of trends were detected in annual river discharge. Déry et al. (2009) detected trends in CV of annual discharges on over $30 \%$ of time series of water discharges observed by Canadian gauges. The authors conclude that this fact "provides observational evidence of an intensifying hydrological cycle in northern Canada, consistent with other regions of the pan-Arctic domain”. Increasing of annual river discharge in Eurasian rivers of is also reported by other studies (Tananaev et al., 2016; Shiklomanov et al., 2006; Peterson et al., 2002), and our estimates are generally in consistence with others. 
Hydrol. Earth Syst. Sci. Discuss., https://doi.org/10.5194/hess-2018-473

Manuscript under review for journal Hydrol. Earth Syst. Sci.

Discussion started: 19 September 2018

345 Generally, all RCP scenarios used in the study predicted similar changes in the mean annual precipitation. The four global models predicted an increase in PRE, ranging from $10 \%$ for the catchments located south of $60^{\circ} \mathrm{N}$ to $60 \%$ for the Eastern Siberian watersheds located north of $60^{\circ} \mathrm{N}$. Similar conclusions on the future increase of precipitation over land surface in the Polar regions are obtained previously by a number of authors (Kusunoki et al., 2015; Prowse et al., 2015; Rawlins et al., 2010; Pavelsky and Smith, 2006). The Arctic amplification of climate warming is projected to be associated with intensification of the water cycle, with increases in precipitation, evaporation and moisture transport from mid-latitudes (Lique et al., 2016; Vihma et al., 2016; Bring et al., 2016; Taylor et al., 2013). Hence, to assess a role of evaporation, the projected values of air temperature need to be included among forcing variables of the MARCS model. This possibility is discussed in Kovalenko et al. (2010), and some studies report improvement of the results on estimations based on historical hindcasts (Shevnina, 2015; Kovalenko et al., 2006).

We note that this study has only addressed projections for the period 2020-2050. Due to the major role of inter-annual and decadal variability, the projected precipitation trends for this period depend on each climate model's realization of these variations. Considering projected changes by the end of the $21^{\text {st }}$ century, the relative importance of inter-annual and decadal variations becomes smaller, and the CMIP5 model projections show more robust trends of increasing precipitation over the Arctic and midlatitudes (Collins et al., 2013; Lique et al., 2016).

Recently, a number of studies have addressed the changes in annual runoff mean values (Prowse et al., 2015; Bengtsson et al., 360 2011; Lehner et al., 2005 ) but do not provide estimates on CV or ARR of 10\% and 90\% exceedance probability. Thus, we can compare our results only with the estimates for the mean values of ARR provided in the previous findings. In particular, Prowse et al. (2015) concludes that "the higher-latitude terrestrial areas of the Arctic are generally becoming more "water rich". The highest increase in mean values of ARR of more than 30-40\% were projected for the catchments in Siberia in the Russian Federation and the Yukon territory in Canada (Döll and Schmidt,2012; Frigon et al., 2010). However, only this study evaluated the

365 ARR values of 10 and $90 \%$ exceedance probability in additional to the mean AAR under each climate projection and climate model output for 173 catchments located over six Arctic member countries.

While numerous studies are addressed to risks for the hydropower production due to climate changes (Parkinson and Djilali, 2015; Hamududu and Killingtveit, 2012; Bengtsson et al., 2011; Seljom et al., 2011), they are mostly based on the future mean values of the annual runoff. In our study, the ARR values of 10 and $90 \%$ exceedance probability allow evaluating the changes in the potential hydropower production of low and hight probability, thus the risks can be evaluated quantitatively, not only qualitative. In this study, we only considered relative changes in the potential hydropower production since the results of the hydrological modeling were aggregated on a country level. It means, that the parameters of the Pearson type 3 distribution simulated by the MARSC model were averaged over the watersheds located within each country. However, the future potential hydropower production can be analyzed in terms of probability also on "basin-by-basin", or even for a site coinciding with an existing

375 hydropower plant. In this case, it is possible to include specific plant details such as hydraulic head and turbine efficiency, and calculate future exceedance probability for potential hydropower production in absolute values.

\section{Conclusions}


Hydrol. Earth Syst. Sci. Discuss., https://doi.org/10.5194/hess-2018-473

Manuscript under review for journal Hydrol. Earth Syst. Sci.

Discussion started: 19 September 2018

(c) Author(s) 2018. CC BY 4.0 License.

Historical time series are losing their role as the only data source for long-term planning of hydropower production. Changing climate is altering the river surface runoff, which is the key hydrological parameter for hydropower production. Several studies have analyzed how global and regional mean annual runoff will change in the future due to climate change. We extended these analyses by estimating the annual runoff of low and high exceedance probability. Long-term probabilistic hydrological projections allowed us to estimate the runoff values together with their exceedance probabilities from the Pearson type 3 distribution, based on the simulations of three parameters (mean value, coefficient of variation and coefficient of skewness). We simulated these three parameters for the period 2020-2050 applying the MARCS model and outputs of four global climate models under three RCP 385 scenarios.

Our analysis indicates that the future potential hydropower production in the territories of Canada, Finland, Norway, Russian Federation, Sweden, and the USA will generally increase regardless of differences between the climate forcing scenarios. However, the magnitude of the increase depends heavily on the forcing. Based on the two models that resulted in so-called wet forcing, climate change will allow for a 10-15\% increase in the potential hydropower generation in the Russian Federation and

390 Fennoscandia, whereas in the USA and Canada, the increase is 4.0- 9.0\%. Based on the two models that resulted in so-called dry forcing, climate change will allow for a $2.1-8.4 \%$ increase in the potential hydropower generation in all the six countries.

The probabilistic form of forecasts provides a solid basis for decision-making in cost-lost situations (Mylne, 2002; Murphy, 1977, 1976). Among the countries addressed in this study, only the United States and Canada have major plans for new hydropower capacity in their territory. Hence, they have the highest potential in incorporating our results in the planning and design of the new 395 plants. However, the uncertainty in the results requires location-specific further analyses on how climate change will affect hydropower production in each catchment. In the other countries addressed, potential increase in hydropower production should be considered during upgrades of the hydropower plants and optimizations of multi-year regulation rules for the plants. In general, the results show that the impacts of climate change should be assessed in detail when hydropower plants are planned and designed.

\section{Data availability}

400 The data files for the MARCS model set up (MARCS_setup.csv), forcing (MARCS_forsing.csv) and output (MARCS_results.csv) were uploaded as supplements to this paper as well as the code behind the Tables 2-6 (Tables_Shevninaetal2018.py).

\section{Author contribution}

E. Shevnina designed the hydrological model and code, collected the data and performed the simulations. K. Pilli-Sihvola and R. 405 Haavisto analysed recent data on the hydropower production in six Arctic member countries. T. Vihma revised the recent trends and the future projections in precipitation and over the Arctic, A. Silaev contributed to define general relationship between water resource and hydropower production. E. Shevnina prepared the manuscript with contributions from all co-authors. 
Hydrol. Earth Syst. Sci. Discuss., https://doi.org/10.5194/hess-2018-473

Manuscript under review for journal Hydrol. Earth Syst. Sci.

Discussion started: 19 September 2018

(c) Author(s) 2018. CC BY 4.0 License.

\section{Competing interests}

The authors declare that they have no conflict of interests.

\section{Acknowledgements}

The study is supported by the Academy of Finland (contract 283101).

\section{References}

Alcamo, J., Döll, P., Henrichs, T., Kaspar, F., Lehner, B., Rösch, T., and Siebert, S.: Development and testing of the WaterGAP 2 global model of water use and availability. Hydrolog. Sci. J., 48(3), 317-338, doi:10.1623/hysj.48.3.317.45290, 4152003.

Aleksandrov, Y. I., Bryazgin, N. N., Førland, E. J., Radionov, V. F., and Svyashchennikov P. N.: Seasonal, interannual and longterm variability of precipitation and snow depth in the region of the Barents and Kara seas, Polar Res., 24(1-2), 69-85, doi:10.1111/j.1751-8369.2005.tb00141.x, 2005.

Averyt, K., Meldrum, J., Caldwell, P., Sun, G., McNulty, S., Huber-Lee, A. and Madden, N.: Sectoral contributions to surface water stress in the coterminous United States, Environ. Res. Lett., 8, 035046, doi:10.1088/1748-9326/8/3/035046, 2013.

Barnston, A. G., and Lyon B.: Does the NMME capture a recent decadal shift toward increasing drought occurrence in the southwestern United States?, J Climate, 29, 561-581, doi:10.1175/JCLI-D-15-0311.1, 2016.

Bengtsson L., Hodges K.I., Koumoutsaris S., Zahn M., Keenlyside N.: The changing atmospheric water cycle in polar regions in a warmer climate Tellus, 63A, 907-920, DOI:10.1111/j.1600-0870.2011.00534.x, 2011.

425 Blackshear, B., Crocker, T., Drucker, E., Filoon, J., Knelman, J., and Skiles, M.: Hydropower Vulnerability and Climate change: a framework for modeling of the future of global hydroelectric resources, available oline at http://www.middlebury.edu/media/view/352071/original, 2011.

Bogdanova, E. G., Gavrilova S. Y., and Il'in B. M.: Time changes of atmospheric precipitation in Russia from the corrected data during 1936-2000, Russ. Meteorol. Hydrol., 35, 706-714, doi:10.3103/S1068373910100092, 2010.

430 Brauman, K.A., Richter, B.D., Postel, S., Malsy, M., and Flörke, M.: Water depletion: An improved metric for incorporating seasonal and dry-year water scarcity into water risk assessments. Elem. Sci. Anth., 4:83, doi: 10.12952/journal.elementa.000083, 2016.

Chylek, P., Li, J., Dubey, M. K., Wang, M., and Lesins, G.: Observed and model simulated $20^{\text {th }}$ century Arctic temperature variability: Canadian Earth System Model CanESM2. Atmos. Chem. Phys. Discuss., 11, 22893-22907, doi:10.5194/acpd-11435 22893-2011, 2011.

Collins, W. J., Bellouin, N., Doutriaux-Boucher, M., Gedney, N., Halloran, P., Hinton, T., Hughes, J., Jones, C. D., Joshi, M., Liddicoat, S., Martin, G., O’Connor, F., Rae, J., Senior, C., Sitch, S., Totterdell, I., Wiltshire, A., and Woodward, S.: Devel- 
Hydrol. Earth Syst. Sci. Discuss., https://doi.org/10.5194/hess-2018-473

Manuscript under review for journal Hydrol. Earth Syst. Sci.

Discussion started: 19 September 2018

(c) Author(s) 2018. CC BY 4.0 License.

opment and evaluation of an Earth-system model - HadGEM2, Geosci. Model Dev. Discuss., 4, 997-1062, doi:10.5194/gmdd-4-997-2011, 2011.

440 Dahmen, E.R., and Hall, M.J.: Screening of hydrological data: tests for stationarity and relative consistency. The Netherlands: International institute for Land reclamation and improvement, 58, 1990.

Domínguez, E., and Rivera, H.: A Fokker-Planck-Kolmogorov equation approach for the monthly affluence forecast of Betania hydropower reservoir, J. Hydroinform., 12(4), 486-501, doi: 10.2166/hydro.2010.083, 2010.

Döll, P., Kaspar, F., and Lehner, B.: A global hydrological model for deriving water availability indicators: model tuning and validation, J Hydrol, 270 (1-2), 105-134, doi: 10.1016/S0022-1694(02)00283-4, 2003.

Döll, P. and Schmied H. M.: How is the impact of climate change on river flow regimes related to the impact on mean annual runoff? A global-scale analysis, Environ. Res. Lett., 7(1), 2012.

Elderton, S.W.P., and Johnson, N.L.: Systems of Frequency Curves, Cambridge University Press, London, 1969.

Falkenmark, M., Lunduist, J., and Widstrand C.: Macro-scale water scarcity requires micro-scale approaches: aspects of vul-

450 nerability in semi-arid development, Nat. Resour. Forum, 13, 258-67, doi:10.1111/j.1477-8947.1989.tb00348.x, 1989.

Fowler, H. J., Blenkinsop, S. and Tebaldi, C.: Linking climate change modelling to impacts studies: recent advances in down-scaling techniques for hydrological modelling, Int. J. Climatol., 27(12), 1547-1578, doi:10.1002/joc.1556, 2007.

Giorgetta, M., Jungclaus, J, Reick, C., Legutke, S., Bader, J., Böttinger, M., Brovkin, V., Crueger, T., Esch, M., Fieg, K., Glushak, K., Gayler, V., Haak, H., Hollweg, H-D., Ilyina, T., Kinne, S., Kornblueh, L., Matei, D., Mauritsen, T., 455 Mikolajewicz, U., Mueller, W., Notz, D., Pithan, F., Raddatz, T., Rast, S., Redler, R., Roeckner, E., Schmidt, H., Schnur, R., Segschneider, J., Six, K., Stockhause, M., Timmreck, C., Wegner, J., Widmann, H., Wieners, K., Claussen, M., Marotzke, J. and Stevens, B.: Climate and carbon cycle changes from 1850 to 2100 in MPI-ESM simulations for the Coupled Model Intercomparison Project phase 5, J Adv Model Earth Sy, 5(3), 572-597, doi:10.1002/jame.20038, 2013.

Hamududu, B., and Killingtveit, A.: Assessing of Climate Change Impacts on Global Hydropower, Energies, 5(2), 305-322, 460 doi:10.3390/en5020305, 2012.

Hartmann, D.L., Klein Tank, A.M.G., Rusticucci, M., Alexander, L.,Brönnimann, S., Charabi, Y., Dentener, F., Dlugokencky, E., Easterling, D., Kaplan, A., Soden, B., Thorne, P., Wild, M., and Zhai P.M.: Observations: Atmosphere and Surface Supplementary Material. In: Climate Change 2013: The Physical Science Basis. Contribution of Working Group I to the Fifth Assessment Report of the Intergovernmental Panel on Climate Change (Stocker, T.F., Qin, D., Plattner, G.-K., Tignor,

465 M., Allen, S.K., Boschung, J., Nauels, A., Xia, Y., Bex V., and Midgley, P.M. (eds.)). Available from www.climatechange2013.org and www.ipcc.ch, last access: 5 September 2018, 2013.

Jakobson, E., and Vihma, T.: Atmospheric moisture budget over the Arctic on the basis of the ERA-40 reanalysis, Int. J. Climatol., 30, 2175-2194, doi:10.1002/joc.2039, 2010.

Jin, M.: Analyzing skin temperature variations from long-term AVHRR, Bull. Amer. Meteor. Soc., 85, 587-600, 2004.

470 Kovalenko V. V.: Maintenance of a stability for modeling and forecasting of a river runoff by methods of a partially infinite hydrology. St. Petersburg, RSHU Publishers, 2011. (In Russian). 
Hydrol. Earth Syst. Sci. Discuss., https://doi.org/10.5194/hess-2018-473

Manuscript under review for journal Hydrol. Earth Syst. Sci.

Discussion started: 19 September 2018

(c) Author(s) 2018. CC BY 4.0 License.

Kovalenko, V. V.: Modeling of hydrological processes, Gidrometizdat, Sankt-Peterburg, 1993. (In Russian).

Kovalenko, V. V., Victorova, N. V., Gaydukova, E. V., Gromova, M. A., Khaustov, V. A. and Shevnina, E. V.: Guideline to estimate a multi-year runoff regime under non-steady climate to design hydraulic contractions, RSHU, Saint-Petersburg, 2010.

475 (In Russian).

Koutrouvelis, I. A., and Canavos, G. C.: Estimation in the Pearson type 3 distribution, Water Resour. Res., 35, 2693-2704, doi:10.1029/1999WR900174, 1999.

Kusunoki, S., Mizuta, R., and Hosaka, M.: Future changes in precipitation intensity over the Arctic projected by a global atmospheric model with a 60-km grid size, Polar Science, 9(3), 277-292, doi:10.1016/j.polar.2015.08.001, 2015.

480 Lehner, B., Czisch, G. and Vassolo, S.: The impact of global change on the hydropower potential of Europe, Energy policy, 33(7), 839-855, doi: 10.1016/j.enpol.2003.10.018, 2005.

Lique, C., Holland, M. M., Dibike,Y. B., Lawrence, D. M., and Screen J. A.: Modeling the Arctic Freshwater System and its integration in the global system: Lessons learned and future challenges, J. Geophys. Res. Biogeosci., 121, doi:10.1002/2015JG003120, 2016.

485 Madany, K. and Lund, J.R.: Modeling California's high-elevation hydropower systems in energy units, Water Resour, Res., 45, W09413, doi:10.1029/2008WR007206, 2009.

Madany, K., and Lund, J.R.: Estimated impacts of climate warming on California's high-elevation hydropower, Climatic Change, 102, 521-538, doi:10.1007/s10584-009-9750-8, 2010.

Madsen, H., Lawrence, D., Lang, M., Martinkova, M., and Kjeldsen, T.R.: A review of applied methods in Europe for flood490 frequency analysis in a changing environment. NERC/Centre for Ecology \& Hydrology on behalf of COST, available from http://nora.nerc.ac.uk/501751/, last access 5 September 2018, 2013.

Matalas, N. C., and Wallis, J. R.: Eureka! It fits a Pearson type: 3 distribution, Water Resour. Res., 9(2), 281-289, doi:10.1029/WR009i002p00281, 1973.

Milly, P., Dunne, K.A., and Vecchia, A.V.: Global pattern of trends in streamflow and water availability in a changing cli495 mate, Nature, 438, 347-350, 2005.

Milly, P., Betancourt, J., Falkenmark, M., Hirsch, R. M., Kundzewicz, Z. W., Lettenmaier, D. P. and Stouffer, R. J.: Stationarity is dead: whither water management, Science, 319, 573-574, 2008.

Mylne, K.R.: Decision-making from probability forecasts based on forecast value. Meteorological Applications 9: 307-315, 2002.

500 Murphy, A.H.: Decision-making models in the cost-loss ratio situation and measures of the value of probability forecasts. Monthly Weather Review 104: 1058-1065; 1976.

Murphy, A.H.: The value of climatological, categorical and probabilistic forecasts in the cost-loss situation, Monthly Weather Review 105: 803-816, 1977. 
Hydrol. Earth Syst. Sci. Discuss., https://doi.org/10.5194/hess-2018-473

Manuscript under review for journal Hydrol. Earth Syst. Sci.

Discussion started: 19 September 2018

(c) Author(s) 2018. CC BY 4.0 License.

Mizuta, R., Yoshimura, H., Murakami, H., Matsueda, M., Endo, H., Ose, T., Kamiguchi, K., Hosaka, M., Sugi, M., 505 Yukimoto, S., Kusunoki, S., Kitoh, A.: Climate simulations using MRI-AGCM3.2 with 20-km grid J. Meteorol. Soc. Jpn., 90A, 213-232, doi:10.2151/jmsj.2012-A12, 2012.

Norden: 10 Insights into the Nordic energy system, available from http://www.nordicenergy.org/wpcontent/uploads/2018/06/10-Insights-A4.pdf last access 5 September 2018, 2018.

Obrezkov, V.I.: Hydroenergy: a handbook for engineers, Moscow: Energoizdat, 1988. (In Russian)

510 Parkinson, S. C., and Djilali, N.: Robust response to hydro-climatic change in electricity generation planning, Climatic Change, 130, 475-489, 2015.

Pavelsky, T.M., and Smith L.C.: Intercomparison of four global precipitation data sets and their correlation with increased Eurasian river discharge to the Arctic Ocean, J. Geophys. Res. Atmos., 111, D21112, doi: 10.1029/2006JD007230, 2006.

Peterson, B. J., Holmes, R. M., McClelland, J. W., Vörösmarty, C. J., Lammers, R. B., Shiklomanov, A. I., Shiklomanov, I.

515 A., and Rahmstorf, S.: Increasing river discharge to the Arctic Ocean, Science, 298, 2171-2173, 2002.

Prowse, T., Bring, A., Mård, J., Carmack, E., Holland, M., Instanes, A., Vihma, T., and Wrona, F. J.: Arctic Freshwater Synthesis: Summary of key emerging issues, J. Geophys. Res. Biogeosci., 120, 1887-1893, doi: 10.1002/2015JG003128, 2015.

Pugachev, V.S., Kazakov, I.E., and Evlanov, L.G.: Basics of statistical theory of automatic system, Mashinostroenie, Moscow, USSR, 1974. (In Russian).

520 Rawlins, M.A., Steele, M., Holland, M.M., Adam, J.C., Cherry, J.E., Francis, J.A., Groisman, P.Y., Hinzman, L.D., Huntington, T.G., Kane, D.L., Kimball, J.S., Kwok, R., Lammers, R.B., Lee, C.M., Lettenmaier, D.P., McDonald, K.C., Podest, E., Pundsack, J.W., Rudels, B., Serreze, M.C., Shiklomanov, A., Skagseth, Ø., Troy, T.J., Vörösmarty, C.J., Wensnahan, M., Wood, E.F., Woodgate, R., Yang, D., Zhang, K., Zhang, T.: Analysis of the Arctic system for freshwater cycle intensification: observations and expectations, J. Clim., 23, 5715-5737, doi:10.1175/2010JCLI3421.1, 2010.

525 Roy, S. B., Ricci, P. F., Summers, K. V., Chung, C.-F., and Goldstein, R. A.: Evaluation of the sustainability of water withdrawals in the United States 1995 to 2025, J. Am. Water Resour. Assoc., 41, 1091-108, doi:10.1111/j.17521688.2005.tb03787.x, 2005.

Rosmann, T., Domíngues, C. E., and Chavarro, J.: Comparing trends in hydrometeorological average and extreme data sets around the world at different time scales, J Hydrol: Regional Studies, 5, 200-212, 2016.

530 Rosmann, T., and Domínguez, C. E.: A Fokker-Planck-Kolmogorov equation-based inverse modelling approach for hydrological systems applied to extreme value analysis, Journal of Hydroinformatics, doi:jh2017079, 2017.

Roshydromet: Second Assessment Report on Climate Change and its Consequences in Russian Federation. General Summary, Roshydromet Federal Service for Hydrometeorol. and Environ. Monit., Moscow, Russia, 2014.

Rozhdestvenskiy, A.V., and Chebotarev, A.I.: Statistical methods in hydrology, Gidrometeizdat, Leningrad, USSR, 1974. (In 535 Russian).

Salvosa, L. R.: Tables of Pearson's Type III Function, Ann. Math. Statist., 1, 191-198, 1930. 
Hydrol. Earth Syst. Sci. Discuss., https://doi.org/10.5194/hess-2018-473

Manuscript under review for journal Hydrol. Earth Syst. Sci.

Discussion started: 19 September 2018

(c) Author(s) 2018. CC BY 4.0 License.

Schwanenberg, D., Xu, M., Ochterbeck, T., Allen, C., and Karimanzira, D.: Short-term management of hydropower assets of the Federal Columbia River Power System Journal of Applied Water Engineering and Research, Taylor \& Francis, 2, 25-32, doi:10.1080/23249676.2014.912952, 2014.

540 Sokolovskiy, D.L.: River runoff (bases on a theory and methods of calculations). Leningrad, Hydrometeoidat, 540 p. 1968. (in Russian)

Shevnina, E. and Krasikov, A. The probabilistic hydrological model MARCS (MARkov Chain System): the core code (Version 1.0), doi:10.5281/zenodo.1220096, 2018.

Shevnina, E., Kourzeneva, E., Kovalenko, V., and Vihma, T.: Assessment of extreme flood events in a changing climate for a

545 long-term planning of socio-economic infrastructure in the Russian Arctic, Hydrol. Earth Syst. Sci., 21, 2559-2578, doi:10.5194/hess-21-2559-2017, 2017.

Shevnina, E., and Gaidukova, E.V.: Hydrological probabilistic model MARCS and its application to simulate the probability density functions of multi-year maximal runoff: the Russian Arctic as a case of study. In book: The Interconnected Arctic UArctic Congress 2016, Springer International Publishing, 77-87, doi: 10.1007/978-3-319-57532-2_8, 2017.

550 Shevnina, E.: Long term probabilistic projections of maximal runoff on the territory of the Russian Arctic. Thesis of the Doctor of Science, Russian State Hydrometeorologcial University. St. Petersburg, 2015. (in Russian)

Taylor, K.E., Stouffer, R.J., and Meehl, G.A.: An overview of CMIP5 and the experiment design, B. Am. Meteorol. Soc., 93, 485-498, 2012.

Tananaev, N. I., Makarieva, O. M., and Lebedeva, L. S.: Trends in annual and extreme flows in the Lena River basin, North-

555 ern Eurasia, Geophys. Res. Lett., 43, 10764-10772, doi:10.1002/2016GL070796, 2016.

Tebaldi, C., and Knutti, R.: The use of the multi-model ensemble in probabilistic climate projections, Phil. Trans. R. Soc. A, 365, 2053-2057, 2007.

Tidwell, V.C., Moreland, B.D., Zemlick, K.M., Roberts, B.L., Passell, H.D., Jensen, D., Forsgren, C., Sehlke, G., Cook, M., King, C.W., and Larsen, S.: Mapping water availability, projected use and cost in the western United States, Environ. Res.

560 Lett., 9, 64009, available online from http://stacks.iop.org/1748-9326/9/i=6/a=064009?key=crossref.cd0324ad178353ade95fa9b01a1d14e6 last access 4 September 2018, 2014.

Tucci, C. E. M., Collischonn, W., Clarke, R. T., Paz, A. R., and Allasia, D.: Short- and long-term flow forecasting in the Rio Grande watershed (Brazil), Atmospheric Science Letters, 9, 53-56, doi:10.1002/asl.165, 2008.

van Gelder, P., Wang, W., Vrijling, J.K.: Statistical estimation methods for extreme hydrological events. In: Extreme Hydro -

565 logical Events: New Concepts for Security (Vasiliev O., van Gelder P., Plate E., Bolgov M. (eds)), NATO Science Series, 78, Springer, Dordrecht, 2006.

Vihma, T., Screen, J., Tjernström, M., Newton, B., Zhang, X., Popova, V., Deser, C., Holland M., and Prowse, T.: The atmospheric role in the Arctic water cycle: A review on processes, past and future changes, and their impacts, J. Geophys. Res. Biogeosci., 121, 586-620, doi:10.1002/2015JG003132, 2016. 
Hydrol. Earth Syst. Sci. Discuss., https://doi.org/10.5194/hess-2018-473

Manuscript under review for journal Hydrol. Earth Syst. Sci.

Discussion started: 19 September 2018

(c) Author(s) 2018. CC BY 4.0 License.

(c) (i)

570 Volodin, E.M., Dianskii, N.A., Gusev, A.V.: Simulating present-day climate with the INMCM4.0 coupled model of the atmospheric and oceanic general circulations, Izvestiya Atmospheric and Oceanic physics, 46(4), 448 - 466, 2010.

Xu, W., Zhang, C.,Peng, Y., Fu, G., and Zhou H.: A two stage Bayesian stochastic optimization model for cascaded hydropower systems considering varying uncertainty of flow forecasts, Water Resour. Res., 50, 9267-9286, doi: 10.1002/2013WR015181, 2014.

575 Xu, H. and Wu, M.: Water Availability Indices-A Literature Review, doi:10.2172/1348938, 2017.

Zarfl, C., Lumsdon, A. E., Berlekamp, J., Tydecks, L., and Tockner, K.: A global boom in hydropower dam construction Aquatic Sciences, 77, 161-170, doi: 10.1007/s00027-014-0377-0, 2015.

Yip, Q. K. Y., Burn, D. H.,Seglenieks, F., Pietroniro A., and Soulis, E. D.: Climate impacts on hydrological variables in the Mackenzie River basin, Can. Water Resour. J. / Rev. Can. Resour. Hydriques, 37(3), 209-230, doi:10.4296/cwrj2011-899, 5802012.

Wilson, E.M.: Surface Runoff. In: Engineering Hydrology, Palgrave, London, 1990. 
Hydrol. Earth Syst. Sci. Discuss., https://doi.org/10.5194/hess-2018-473

Manuscript under review for journal Hydrol. Earth Syst. Sci.

(c) Author(s) 2018. CC BY 4.0 License.

Discussions

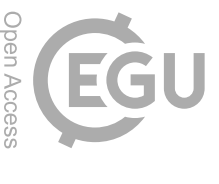

(c) (i)

Table 1. Overview of the runoff dataset used in the study

\begin{tabular}{|c|c|c|c|c|c|c|}
\hline \multirow[t]{2}{*}{ Country } & & \multirow{2}{*}{$\begin{array}{c}\text { Number of } \\
\text { gauges }\end{array}$} & \multicolumn{2}{|c|}{ Catchment area, $\mathrm{km}^{2}$} & \multicolumn{2}{|c|}{ Length of time series, year } \\
\hline & & & $\min$ & $\max$ & $\min$ & $\max$ \\
\hline Finland & FI & 8 & 5160 & 19839 & 43 & 151 \\
\hline Sweden & SE & 10 & 5479 & 23102 & 51 & 113 \\
\hline Norway & NO & 8 & 5163 & 20300 & 38 & 131 \\
\hline Russia & RF & 121 & 5000 & 25000 & 30 & 123 \\
\hline Canada & CA & 86 & 5050 & 24800 & 34 & 103 \\
\hline United States & US & 93 & 5053 & 24786 & 33 & 139 \\
\hline
\end{tabular}


Hydrol. Earth Syst. Sci. Discuss., https://doi.org/10.5194/hess-2018-473

Manuscript under review for journal Hydrol. Earth Syst. Sci.

(c) Author(s) 2018. CC BY 4.0 License.

Table 2. The MARCS model setup for catchments located over the territory of the six countries

\begin{tabular}{ccccccccc}
\hline \multirow{2}{*}{$\begin{array}{c}\text { Country } \\
\text { code }\end{array}$} & IRC & \multicolumn{2}{c}{ M1, $\mathrm{mm} \mathrm{yr}^{-1}$} & \multicolumn{2}{c}{ CV } & \multicolumn{2}{c}{ CS/CV } & \multicolumn{2}{c}{ PRE, $\mathrm{mm} \mathrm{yr}^{-1}$} \\
\cline { 3 - 8 } & Ave* & Ave & Min / Max & Ave & Min / Max & Ave & Ave & Min / Max \\
\hline FI & 1.8 & 329 & $267 / 379$ & 0.21 & $0.19 / 0.24$ & 0.5 & 591 & $508 / 630$ \\
\hline SE & 1.7 & 377 & $234 / 464$ & 0.21 & $0.17 / 0.28$ & 1.5 & 601 & $516 / 709$ \\
\hline NO & 1.1 & 446 & $372 / 590$ & 0.19 & $0.17 / 0.21$ & 2.5 & 459 & $374 / 601$ \\
\hline RF & 1.9 & 248 & $47.5 / 546$ & 0.27 & $0.14 / 0.77$ & 2.0 & 464 & $218 / 834$ \\
\hline CA & 1.9 & 344 & $50.9 / 1285$ & 0.26 & $0.10 / 0.60$ & 1.5 & 661 & $274 / 1909$ \\
\hline US & 2.1 & 353 & $57.5 / 1103$ & 0.34 & $0.12 / 0.73$ & 2.0 & 752 & $266 / 1465$ \\
\hline
\end{tabular}

* Ave is the value averaged over river basins located within a country 
Hydrol. Earth Syst. Sci. Discuss., https://doi.org/10.5194/hess-2018-473

Manuscript under review for journal Hydrol. Earth Syst. Sci.

Discussion started: 19 September 2018

(c) Author(s) 2018. CC BY 4.0 License.
Hydrology and Earth System

Sciences

Discussions

(c) (i)

Table 3. Mean values of annual precipitation rate $\left(\mathrm{PRE}_{2050}, \mathrm{~mm} \mathrm{yr}^{-1}\right)$ calculated from the outputs of the four global climate models

for 2020-2050

\begin{tabular}{|l|c|c|c|c|c|c|}
\hline \multirow{2}{*}{$\begin{array}{l}\text { Climate } \\
\text { projection }\end{array}$} & FI & SE & CA & RF & CA & US \\
\cline { 2 - 7 } CAD-26* & 662 & 687 & 532 & 538 & 723 & 805 \\
\hline CAD-45 & 643 & 676 & 527 & 526 & 714 & 792 \\
\hline CAD-85 & 643 & 676 & 527 & 526 & 714 & 792 \\
\hline HAD-26 & 601 & 603 & 447 & 497 & 663 & 759 \\
\hline HAD-45 & 601 & 615 & 489 & 502 & 691 & 748 \\
\hline HAD-85 & 589 & 617 & 469 & 489 & 658 & 760 \\
\hline MPI-26 & 647 & 646 & 533 & 531 & 716 & 775 \\
\hline MPI-45 & 642 & 675 & 522 & 510 & 714 & 767 \\
\hline MPI-85 & 678 & 656 & 539 & 528 & 722 & 759 \\
\hline INM-45 & 609 & 620 & 465 & 480 & 692 & 763 \\
\hline INM-85 & 617 & 653 & 502 & 498 & 715 & 736 \\
\hline
\end{tabular}

* - the outputs for the CaEMS2 (CAD), HadGEM2-ES (HAD), MPI-ES-LR (MPI) and INMCM4 (INM) climate models under RCP2.6 (-26), RCP4.5 (-45) and RCP8.5 (-85) scenarios. 
Hydrol. Earth Syst. Sci. Discuss., https://doi.org/10.5194/hess-2018-473

Manuscript under review for journal Hydrol. Earth Syst. Sci.

Discussion started: 19 September 2018

(C) Author(s) 2018. CC BY 4.0 License.

(c) (1)
Hydrology and Earth System Sciences

Discussions

Table 4. The projected mean values of ARR (M1 $\left.\mathbf{M}_{2050}\right)$ simulated by the MARCS hydrological model under the forcing 595 of the CaEMS2, HadGEM2-ES, MPI-EMS-LM and INMCM4 climate models

\begin{tabular}{|c|c|c|c|c|c|c|c|}
\hline \multirow[t]{2}{*}{ Climate model } & \multirow[t]{2}{*}{ Scenario } & \multicolumn{6}{|c|}{$\mathrm{M}_{2050}\left(\mathrm{~mm} \mathrm{yr}^{-1}\right)$ by country } \\
\hline & & FI & SE & NO & $\mathrm{RF}$ & CA & US \\
\hline \multirow[t]{3}{*}{ CaEMS2 } & RCP26 & 367 & 432 & 516 & 288 & 377 & 377 \\
\hline & RCP45 & 357 & 422 & 512 & 282 & 373 & 371 \\
\hline & RCP85 & 357 & 422 & 512 & 282 & 373 & 371 \\
\hline \multirow[t]{3}{*}{ MPI-EMS-LM } & RCP26 & 360 & 409 & 517 & 285 & 374 & 364 \\
\hline & RCP45 & 358 & 426 & 507 & 272 & 374 & 362 \\
\hline & RCP85 & 377 & 416 & 523 & 284 & 379 & 357 \\
\hline \multicolumn{2}{|c|}{$\mathrm{M1}_{2050}$ : "wet" forcing } & 363 & 421 & 515 & 282 & 375 & 367 \\
\hline \multirow[t]{3}{*}{ HadGEM2-ES } & RCP26 & 334 & 378 & 435 & 267 & 349 & 359 \\
\hline & RCP45 & 336 & 390 & 475 & 267 & 362 & 355 \\
\hline & RCP85 & 328 & 386 & 457 & 261 & 345 & 361 \\
\hline \multirow[t]{2}{*}{ INMCM4 } & RCP45 & 338 & 391 & 452 & 257 & 362 & 362 \\
\hline & RCP85 & 343 & 409 & 488 & 266 & 374 & 348 \\
\hline \multicolumn{2}{|c|}{$\mathrm{M} 1_{2050}$ : “dry” forcing } & 336 & 391 & 461 & 264 & 358 & 357 \\
\hline \multicolumn{8}{|c|}{ M1: after (Rogdestvenskiy and } \\
\hline \multicolumn{2}{|c|}{$\begin{array}{l}\text { Chebotarev, 1974) for the } \\
\text { reference period }\end{array}$} & 329 & 377 & 446 & 248 & 344 & 353 \\
\hline
\end{tabular}


Hydrol. Earth Syst. Sci. Discuss., https://doi.org/10.5194/hess-2018-473

Table 5. The coefficients of variation of ARR $\left(\mathrm{CV}_{2050}\right)$ averaged over the catchments selected

\begin{tabular}{|c|c|c|c|c|c|c|c|}
\hline \multirow[t]{2}{*}{ Climate model } & \multirow[t]{2}{*}{ Scenario } & \multicolumn{6}{|c|}{$\mathrm{CV}_{2050}$ by country } \\
\hline & & FI & SE & NO & $\mathrm{RF}$ & CA & US \\
\hline \multirow[t]{3}{*}{ CaEMS2 } & RCP26 & 0.19 & 0.19 & 0.18 & 0.25 & 0.25 & 0.33 \\
\hline & RCP45 & 0.19 & 0.19 & 0.18 & 0.25 & 0.25 & 0.33 \\
\hline & RCP85 & 0.19 & 0.19 & 0.18 & 0.25 & 0.25 & 0.33 \\
\hline \multirow[t]{3}{*}{ MPI-EMS-LM } & RCP26 & 0.19 & 0.20 & 0.18 & 0.25 & 0.25 & 0.33 \\
\hline & RCP45 & 0.19 & 0.19 & 0.18 & 0.25 & 0.25 & 0.34 \\
\hline & RCP85 & 0.19 & 0.20 & 0.18 & 0.25 & 0.25 & 0.34 \\
\hline \multicolumn{2}{|c|}{$\mathrm{CV}_{2050}$ : average wet forcing } & 0.19 & 0.20 & 0.18 & 0.25 & 0.25 & 0.33 \\
\hline \multirow[t]{3}{*}{ HadGEM2-ES } & RCP26 & 0.21 & 0.21 & 0.19 & 0.26 & 0.27 & 0.34 \\
\hline & RCP45 & 0.21 & 0.21 & 0.18 & 0.26 & 0.26 & 0.35 \\
\hline & RCP85 & 0.21 & 0.20 & 0.19 & 0.26 & 0.27 & 0.34 \\
\hline \multirow[t]{2}{*}{ INMCM4 } & RCP45 & 0.21 & 0.21 & 0.19 & 0.26 & 0.26 & 0.34 \\
\hline & RCP85 & 0.20 & 0.20 & 0.18 & 0.26 & 0.25 & 0.35 \\
\hline \multicolumn{2}{|c|}{$\mathrm{CV}_{2050}$ : average dry forcing } & 0.21 & 0.20 & 0.19 & 0.26 & 0.26 & 0.34 \\
\hline \multicolumn{8}{|c|}{ CV: after (Rogdestvenskiy and } \\
\hline \multicolumn{2}{|c|}{$\begin{array}{l}\text { Chebotarev, 1974) for the } \\
\text { reference period }\end{array}$} & 0.21 & 0.21 & 0.19 & 0.27 & 0.27 & 0.34 \\
\hline
\end{tabular}


Hydrol. Earth Syst. Sci. Discuss., https://doi.org/10.5194/hess-2018-473

(c) Author(s) 2018. CC BY 4.0 License.

Table 6. The ordinates of Pt3 distribution (k10/k90) and annual runoff rate (ARR10/ARR90, $\mathrm{mm}^{\text {year }}{ }^{-1}$ ) for low $(10 \%)$ and high $(90 \%)$ exceedance probabilities under wet and dry forcing: the aggregation on country level

\begin{tabular}{|c|c|c|c|c|c|c|c|}
\hline Time period & Values & FI & SE & NO & RU & CA & US \\
\hline \multirow{4}{*}{ Reference } & k10 & 1.270 & 1.270 & 1.247 & 1.350 & 1.350 & 1.446 \\
\hline & k90 & 0.730 & 0.730 & 0.759 & 0.654 & 0.654 & 0.575 \\
\hline & ARR10 & 418 & 479 & 556 & 335 & 464 & 510 \\
\hline & ARR90 & 240 & 275 & 339 & 162 & 225 & 203 \\
\hline \multirow{4}{*}{$\begin{array}{l}\text { Projected } \\
\text { wet forcing }\end{array}$} & $\mathrm{k} 10_{2050}$ & 1.247 & 1.260 & 1.234 & 1.325 & 1.325 & 1.432 \\
\hline & $\mathrm{k} 90_{2050}$ & 0.759 & 0.744 & 0.770 & 0.680 & 0.680 & 0.575 \\
\hline & ARR10 $_{2050}$ & 413 & 485 & 561 & 341 & 463 & 511 \\
\hline & $\mathrm{ARR}{ }_{2050}$ & 251 & 286 & 350 & 175 & 237 & 205 \\
\hline \multirow{4}{*}{$\begin{array}{l}\text { Projected with } \\
\text { dry forcing }\end{array}$} & $\mathrm{k} 10_{2050}$ & 1.270 & 1.260 & 1.247 & 1.338 & 1.338 & 1.446 \\
\hline & k90 2050 & 0.730 & 0.744 & 0.759 & 0.667 & 0.667 & 0.575 \\
\hline & ARR10 2050 & 426 & 492 & 575 & 353 & 480 & 516 \\
\hline & ARR90 $_{2050}$ & 245 & 291 & 350 & 176 & 239 & 205 \\
\hline
\end{tabular}


Hydrol. Earth Syst. Sci. Discuss., https://doi.org/10.5194/hess-2018-473

Manuscript under review for journal Hydrol. Earth Syst. Sci.

Discussion started: 19 September 2018

(c) Author(s) 2018. CC BY 4.0 License.

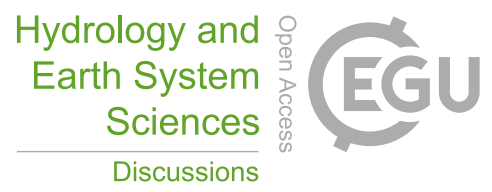

\begin{tabular}{|c|c|c|c|}
\hline & CLIMATOLOGY & HYDROLOGY & HYDROPOWER \\
\hline & $\begin{array}{l}\text { Historical yearly time } \\
\text { series of river discharges } \\
\text { (326 sites) } \\
\text { Historical time series of } \\
\text { annual precipitation } \\
\text { (gridded) } \\
\text { Projected time series of } \\
\text { annual precipitation } \\
\text { (gridded) }\end{array}$ & $\begin{array}{l}\text { - Mean, coefficient of } \\
\text { variation (CV) and } \\
\text { coefficient of skewness } \\
\text { (CS) at sites } \\
\text { - Mean annual precipitation } \\
\text { (historical and protected) at } \\
\text { river catchments }\end{array}$ & $\begin{array}{l}\text { Projected annual river } \\
\text { discharge at sites in a } \\
\text { form of an exceedance } \\
\text { probability curve (EPC): } \\
\text { limited by mean, low and } \\
\text { hight exceedance } \\
\text { probability }\end{array}$ \\
\hline & $\begin{array}{l}\text { Statistical estimators of } \\
\text { non-central moments }\end{array}$ & $\begin{array}{l}\text { Advance of frequency } \\
\text { analysis resulting to the } \\
\text { probabilistic hydrological } \\
\text { model MARcov Chain } \\
\text { System, MARCS, v0.2 }\end{array}$ & $\begin{array}{l}\text { General relationship } \\
\text { between hydroenergy } \\
\text { production and water } \\
\text { resource (the annual river } \\
\text { discharge) }\end{array}$ \\
\hline & $\begin{array}{l}\text { - Mean, coefficient of } \\
\text { variation and coefficient } \\
\text { of skewness } \\
\text { - Mean value of annual } \\
\text { precipitation (historical } \\
\text { and protected) }\end{array}$ & $\begin{array}{l}\text { Projected annual river } \\
\text { discharge at sites in a } \\
\text { form of an exceedance } \\
\text { probability curve (EPC) }\end{array}$ & $\begin{array}{l}\text { Potential hydropower } \\
\text { production (PHP) }\end{array}$ \\
\hline
\end{tabular}

Figure 1: A schematic presentation of the study method. 
Hydrol. Earth Syst. Sci. Discuss., https://doi.org/10.5194/hess-2018-473

Manuscript under review for journal Hydrol. Earth Syst. Sci.

Discussion started: 19 September 2018

(c) Author(s) 2018. CC BY 4.0 License.

(c) (i)

\section{Hydrology and Earth System Sciences \\ Discussions}

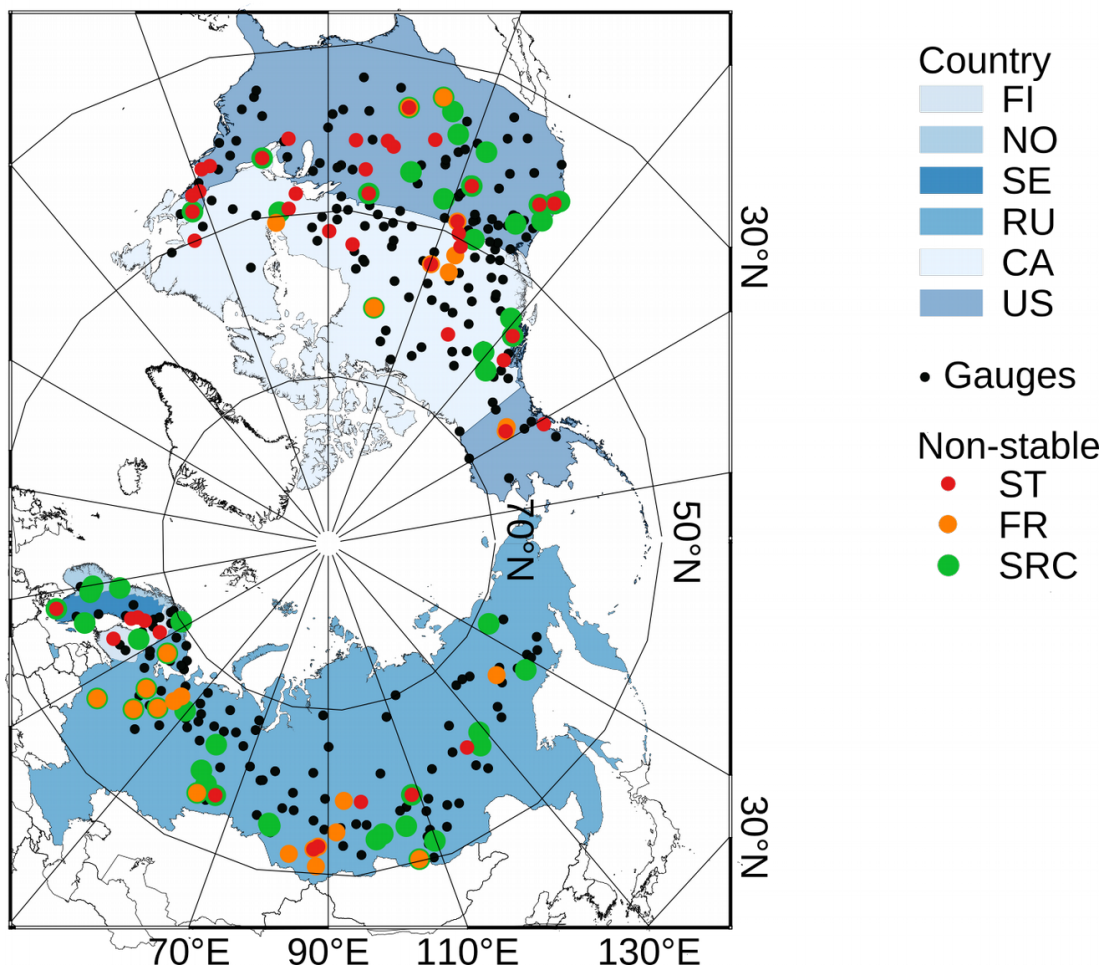

Figure 2. Location of the catchments studied. The black dots indicate gauges with homogeneous time series, whereas the red/orange dots indicate gauges with the statistically significant changes in the mean or variance (based on the Student ttest (ST) and Fisher's F-test (FR)), and the green dots mark the gauges with significant trends in observed time series (based on the Spearman Rank-Correlation Test (SRC)). 
Hydrol. Earth Syst. Sci. Discuss., https://doi.org/10.5194/hess-2018-473

Manuscript under review for journal Hydrol. Earth Syst. Sci.

Discussion started: 19 September 2018

(c) Author(s) 2018. CC BY 4.0 License.
Hydrology and

Earth System Sciences

Discussions

(c) $\underset{\mathrm{BY}}{(i)}$

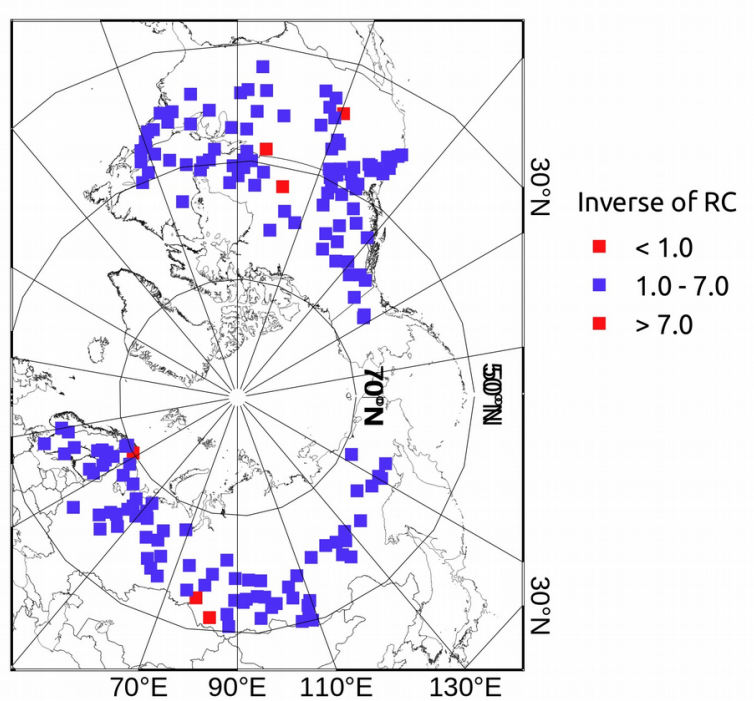

a)

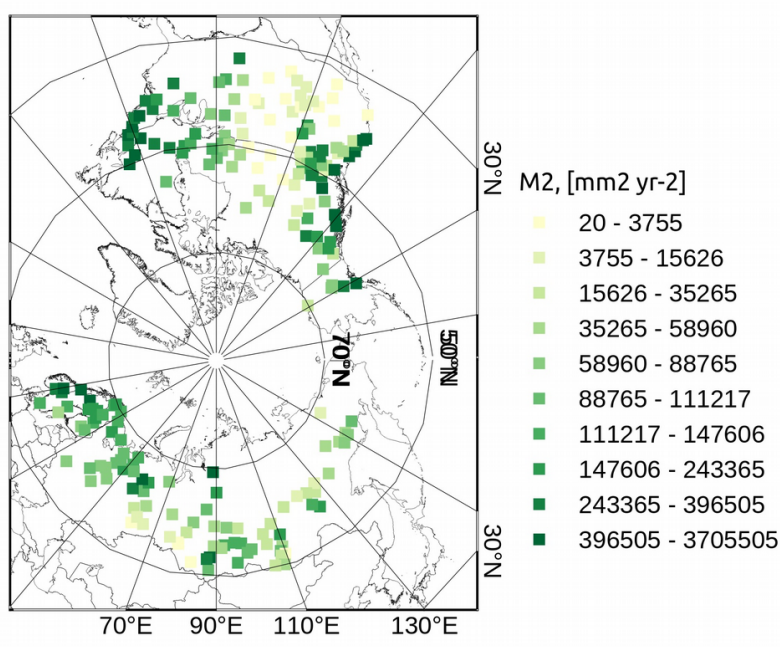

c)

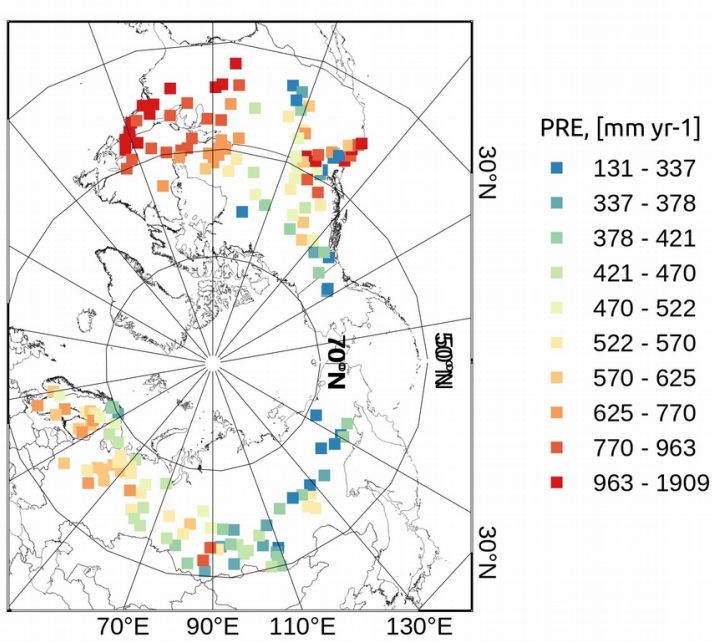

b)

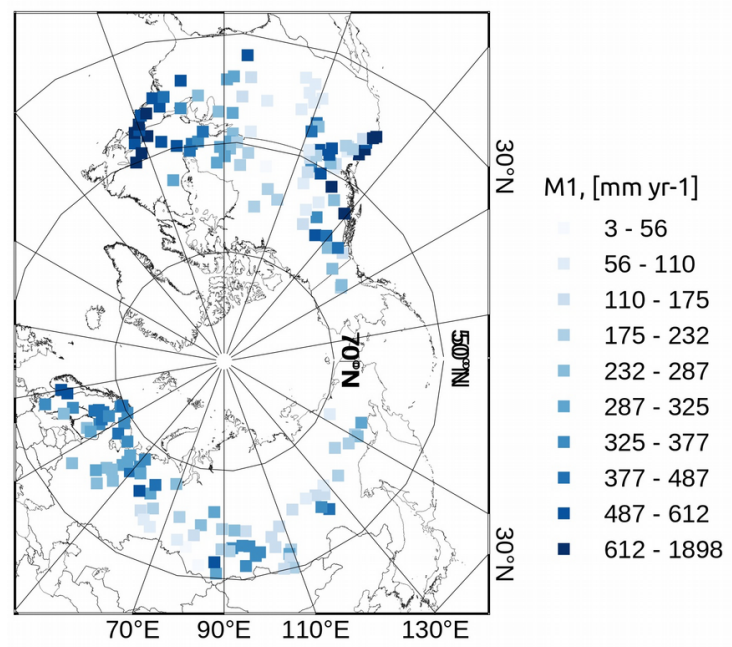

d)

Figure 3. The MARCS model set-up for the Arctic for the reference period: a) the inverse of runoff coefficient (IRC); b) the mean value of annual precipitation rate (PRE, $\left.\mathrm{mm} \mathrm{yr}^{-1}\right)$; c) the second non-central moment estimate (M2, $\left.\mathrm{mm}^{2} \mathrm{yr}^{-2}\right)$; d) the first non-central moment estimate, mean annual runoff rate (M1, $\mathrm{mm} \mathrm{yr}^{-1}$ ). 
Hydrol. Earth Syst. Sci. Discuss., https://doi.org/10.5194/hess-2018-473

Manuscript under review for journal Hydrol. Earth Syst. Sci.

Discussion started: 19 September 2018

(c) Author(s) 2018. CC BY 4.0 License.
Hydrology and

Earth System Sciences

Discussions

(c) (1)
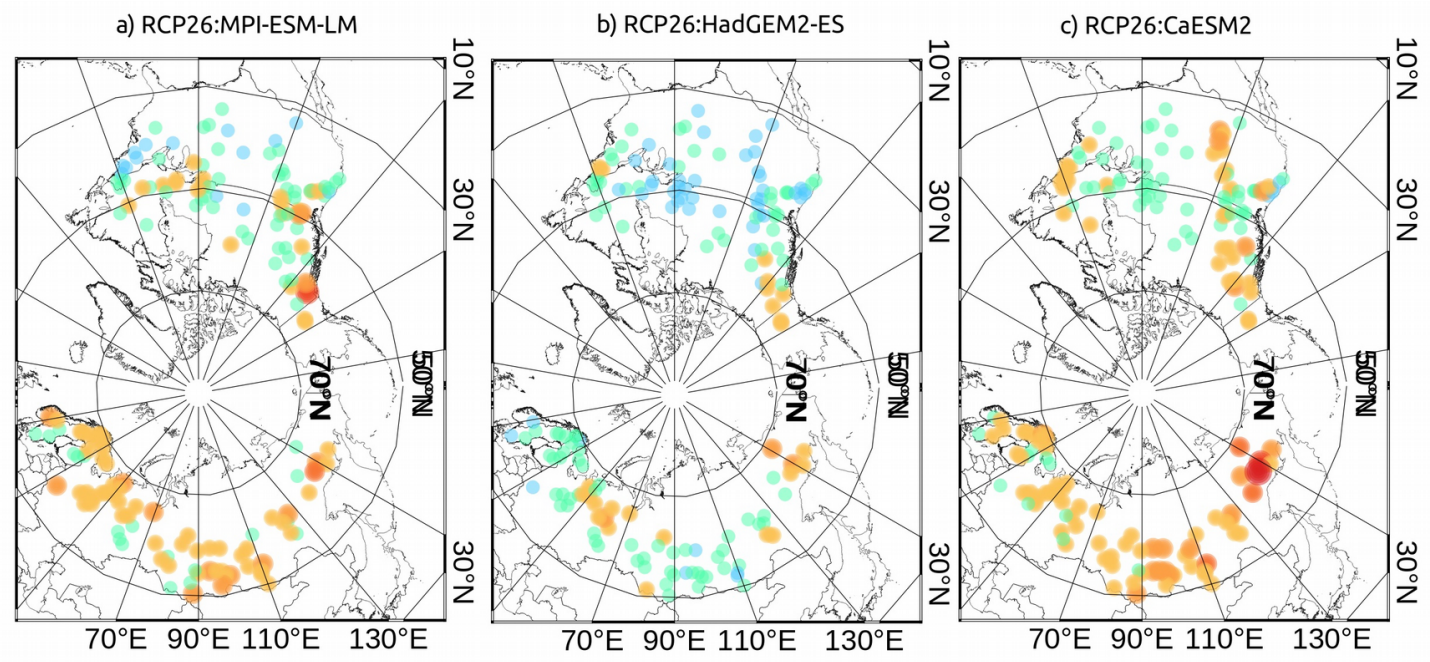

dPRE, \%

$-10-0$

$0-10$

d) RCP85:MPI-ESM-LM

e) RCP85:HadGEM2-ES

f) RCP85:CaESM2
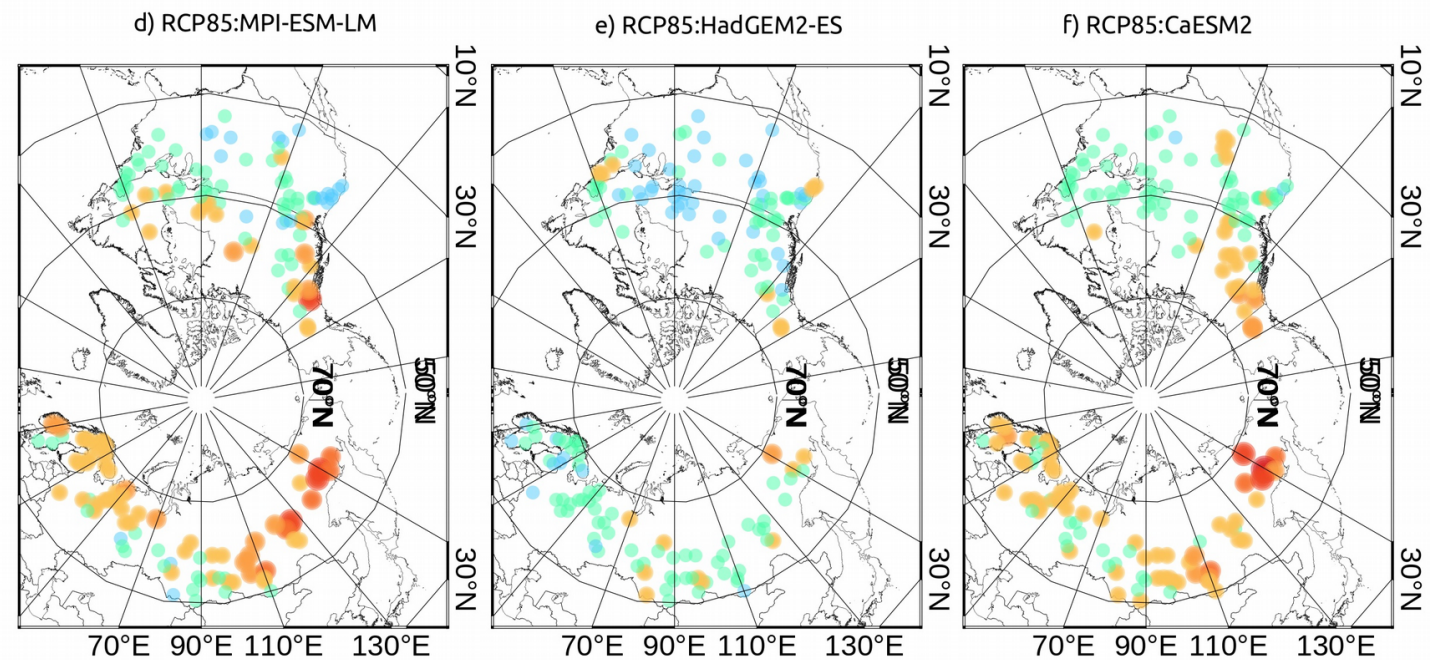

$10-20$

$20-30$

- $30-40$

$40-50$

- $50-60$

$60-70$

Figure 4. Projected changes in mean annual precipitation ( $\left.\mathrm{dPRE}_{2050}, \%\right)$ at the catchments selected 
Hydrol. Earth Syst. Sci. Discuss., https://doi.org/10.5194/hess-2018-473

Manuscript under review for journal Hydrol. Earth Syst. Sci.

Discussion started: 19 September 2018

(c) Author(s) 2018. CC BY 4.0 License.

Hydrology and

Earth System

Sciences

Discussions

(c) (1)

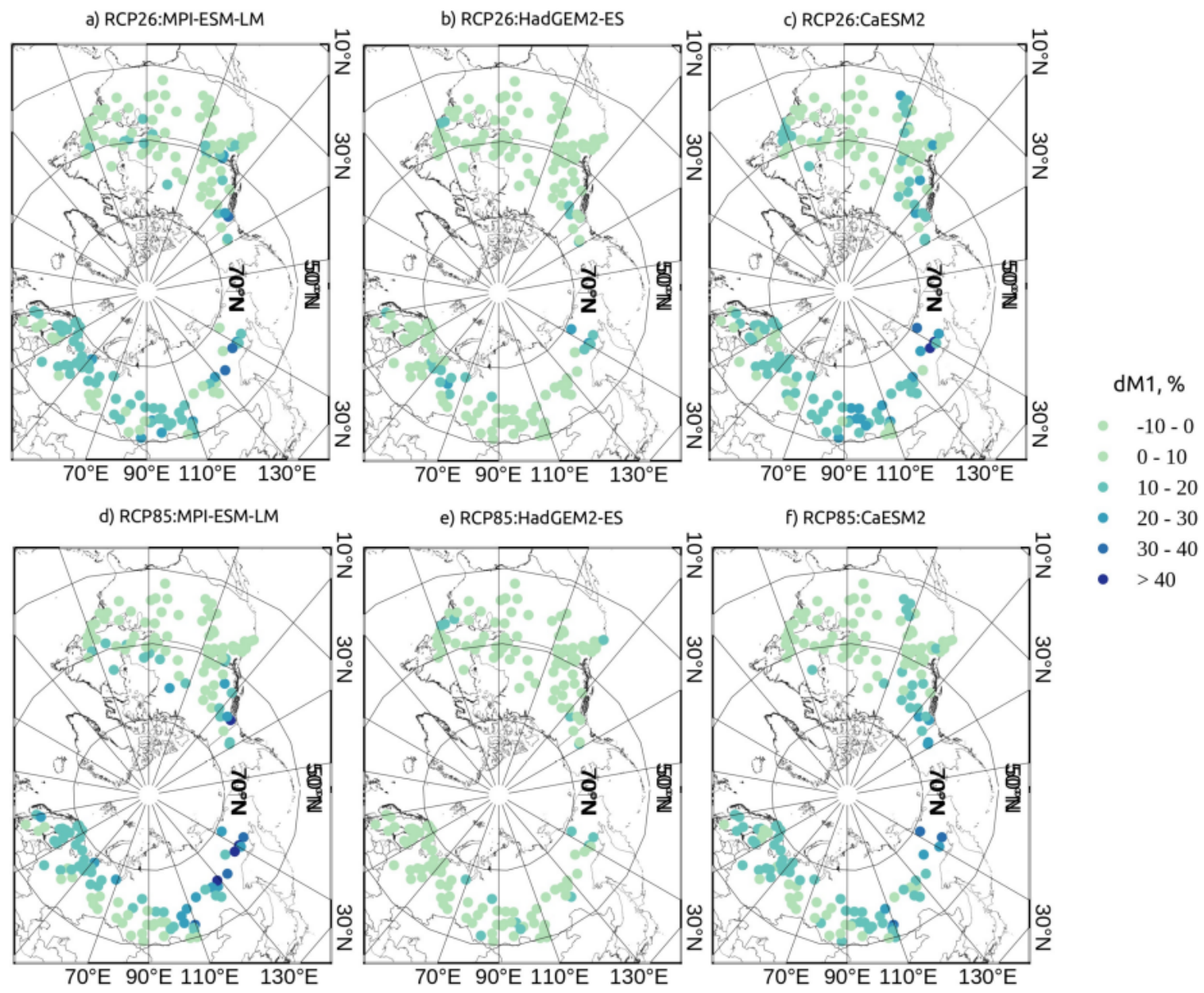

Figure 5. Relative changes of the projected means of ARR (dM1 2050 , \%) for the RCP26 (top) and RCP85 (bottom) 
Hydrol. Earth Syst. Sci. Discuss., https://doi.org/10.5194/hess-2018-473

Manuscript under review for journal Hydrol. Earth Syst. Sci.

Discussion started: 19 September 2018

(c) Author(s) 2018. CC BY 4.0 License.

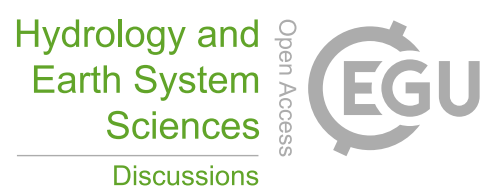

(c) (i)

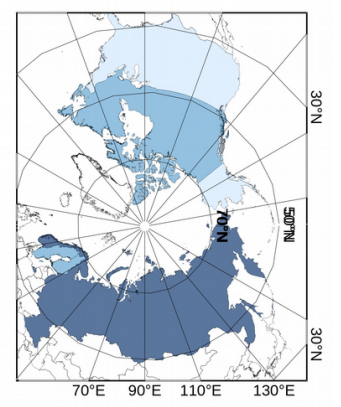

a) wet

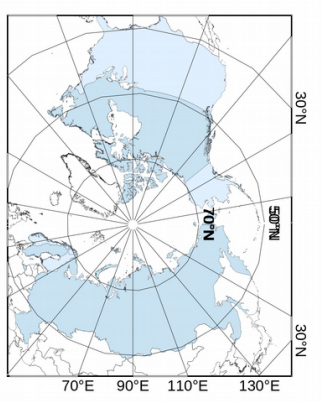

b) dry

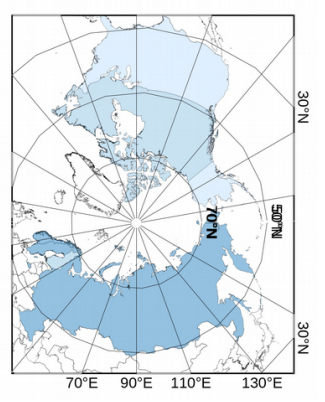

c) wet

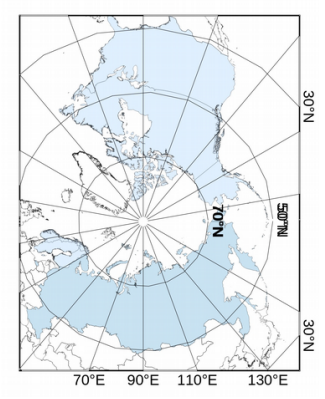

d) dry

$\mathrm{dPHP}, \%$

$$
<5.0
$$$$
5.0-10.0
$$$$
10.0-15.0
$$

$>15.0$

625 Figure 6. Relative change of the potential hydropower production $\left(\mathbf{d P H P}_{2050}\right)$ in six Arctic Council member countries according to dARR90 2050 (a, b) and dARR10 2050 (c, d) under the wet and dry forcing 